\title{
PŘIJÍMACÍ ŘÍZENÍ NA STŘEDNÍCH ODBORNÝCH ŠKOLÁCH V OBDOBÍ SOCIALISTICKÉHO ČESKOSLOVENSKA
}

\author{
THE ADMISSION PROCEDURE \\ AT SECONDARY VOCATIONAL SCHOOLS \\ IN SOCIALIST CZECHOSLOVAKIA
}

\author{
MICHAL ŠIMÁNĚ, LENKA KAMANOVÁ
}

\begin{abstract}
Abstrakt
Tématem studie je problematika stredního odborného školství v obdobi socialistického Československa. Konkrétním cílem autoru textu je zachytit a interpretovat prüběh prïjimacího rízení a jeho promèny na tomto typu škol během jednačtyricetiletého obdobi vlády Komunistické strany Céskoslovenska (1948-1989). Výzkum vycházi z historiografického proudu dĕjin každodennosti. Jednou z použitých metod výzkumu je orálni historie založená na rozhovorech s pamétniky - učiteli, kteř́ ve sledovaném obdobi prisobili na strednich odborných školách. Výžum prostrednictvím metody orální historie je dále doplnèn studiem dobové legislativy a dobových periodik, jako jsou časopisy Odborná škola či Nová škola, a studiem archivních materiáli ziśskaných v Národnim archivu v Praze. Výsledky studie prinášeji dosud nezachycený obraz. prüběbu a promèn prijímacíbo rízeneni na stréednich odborných školách v obdobi socialistickébo Ceskoslovenska. Ukazuje ideologické zásaby komunistickébo režimu do podoby prijímacího ríżeni napr. prostrédnictvím

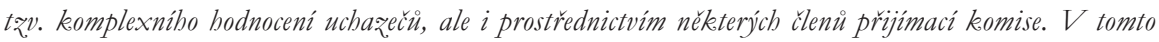
obledu zejména na príkladu predsedy prijímaci komise, kterou v mnoba př́padech zastával reditel střední odborné školy.
\end{abstract}

\section{Klíčová slova}

prijimaci ř́zeni, stredni odborné školy, komplexni hodnoceni, ředitel školy, socialistické Československo, déjiny každodennosti, orálni historie

\footnotetext{
Abstract

The topic of this study is the issue of secondary vocational schools in socialist Czechoslovakia. The specific aim of this paper is to capture and interpret the course of the admission procedure and its transformation at this type of school during the 41-year rule of the Communist Party of Czechoslovakia (1948-1989). The research is based on a historiographic approach to the history of everyday life. One of the research methods
} 
used is an oral history based on interviews with witnesses: teachers who worked at secondary vocational schools during the socialist regime. Our research is further complemented by the study of period legislation and periodicals, such as Odborná śskola and Nová skoola, and archival sources obtained from the National Archive in Prague. The results of the study provide a previously unrevealed picture of the course and transformation of the admission procedure at secondary vocational schools in socialist Czechoslovakia. They show the ideological interventions of the Communist regime into the form of the admission procedure, for instance through the so-called comprehensive evaluation report of applicants and also through some members of the admission committee. The study pays particular attention to the role of the chairman of the admission committee, which in many cases was held by the headteacher of a secondary vocational school.

\section{Keywords}

admission procedure, secondary vocational schools, comprehensive evaluation report, headteacher, socialist Czechoslovakia, history of everyday life, oral history

\section{Úvod}

Pro vývoj československého státu v druhé polovině 20. století se stal zásadní tzv. únorový puč z roku 1948, kdy Komunistická strana Československa (dále KSČ) získala ve státě veškerou politickou moc. Na dalších více než čtyřicet let tato strana autokraticky určovala směr vývoje československé společnosti, který měl být po období socialismu završen dosažením komunismu (viz nap̌r. Swain \& Swain, 1998). Není proto překvapující, že do mnoha oblastí života společnosti i života jednotlivých obyvatel Československa začala KSČ silně prosazovat ideologii marxismu-leninismu. Školství v tomto směru nebylo výjimkou. Ba naopak se stalo jednou z prioritních oblastí, na kterou KSČ zaměřila svou pozornost. Vedení KSČ totiž neuniklo, že právě oblast školství může být jedním z prostředků, kterým lze vychovat nové generace „pracujícího lidu“ a inteligence loajální k ideologickým myšlenkám marxismuleninismu. Koneckonců, jak uvádí ve své publikaci Zounek et al. (2018, s. 5), učitelé se doslova měli stát „důležitým ideologickým nástrojem, s jehož pomocí strana vyzbrojuje dorůstající generace i masy komunistickou morálkou“. Podoba vzdělávacího systému měla proto plně odpovídat potřebám nové státní ideologie. Cíle, obsah, metody výuky a další měly být $\mathrm{v}$ naprostém souladu s myšlenkami marxismu-leninismu.

Nejednalo se ovšem o jediný úkol kladený komunistickou stranou na tehdejší školy. Nový režim s sebou totiž přinesl i novou orientaci v oblasti hospodářství. Podobně jako v jiných oblastech i v oblasti hospodářství se tehdejší vláda silně inspirovala př́kladem Sovětského svazu. $V$ tomto směru se jednalo např́ḱlad o tzv. Stalinský plán přetvoření přírody, který byl oficiálně spuštěn $\mathrm{v}$ roce 1948. Tuto $\mathrm{v}$ podstatě sovětskou vizi budování socialismu, jak uvádí Olšáková a Janáč (2018), představitelé KSČ pod vedením sovětských poradců mechanicky přejali a promítli do svého prvního pětiletého plánu 
rozvoje hospodářství v Československu (probíhal v letech 1949-1953) ve formě silné industrializace zejména dosud agrárních oblastí (především na Slovensku) a posílením strojírenského a chemického průmyslu či hutnictví (obzvláště na Ostravsku-Karvinsku). Přijetí tohoto plánu zároveň vyvolalo s ohledem na splnění jeho cílů celonárodní mobilizaci mas. Nepřekvapí proto, že nedílnou součástí tohoto plánu (a de facto i všech dalších plánů rozvoje hospodářství v Československu) se stal i plán na př́pravu odborníků na všech úrovních školství, tedy i na stř̌edních odborných školách ${ }^{1}$, na které je zaměřena tato studie (více viz např. Zákon č. 241/1948). Není proto náhoda, že již od roku 1949 se školy začaly podílet na jeho plnění např́íklad v podobě náboru žáků do hornického povolání (v rámci tzv. Lánské akce) či v podobě tzv. hnutí vesnických učitelů, které mělo podporovat zakládání jednotných zemědělských družstev (více viz např. Kourová, 2017; Vorlíček, 2004).

Dalším významným charakteristickým prvkem nejenom odborného školství v socialistickém Československu, jak si všímá např́íklad Simonová (2011), byla snaha KSČ o snížení nerovností v př́ístupu ke vzdělávání. Jednalo se v podstatě o programové, ideologické a politicko-mocenské odstraňování tř́dních nerovností ve společnosti (Boguszak et al., 1990). Vzdělávání mělo být jednotné, zdarma a dostupné všem. To se odráží také v některých formulacích nového školského zákona (tzv. Nejedlého zákona), který byl přijat již v dubnu roku 1948. Ačkoliv tento legislativní akt byl připravován dlouhou dobu před únorovým pučem, byla schválena verze, ve které je silně patrné pronikání ideologie vládnoucí strany. Školy na jednu stranu začaly bezplatně zajišt'ovat žákům společný vzdělávací základ i stejný př́stup k dalšímu vzdělávání, na druhou stranu se začaly silně orientovat na socialistické požadavky KSČ. Ty se přitom projevovaly nejenom v obsahu vzdělávání, př́ípadně zestátněním či zrušením všech soukromých škol, ale také např́ílad kádrovou politikou vůči žákům, kdy začali být upřednostňováni žáci pocházející z dělnického či rolnického prostředí (viz Zákon č. 95/1948; Vorlíček, 2004).

1 Pojmenování středních škol zaměřených primárně na profesní přípravu, jejichž absolvování zároveň umožňovalo pokračovat ve studiu na vysoké škole (podle současné mezinárodní klasifikace vzdělávání ISCED 11 se jedná o školy spadající do stupně ISCED 354), se v průběhu socialistického Československa měnilo. Např́iklad v letech 1948-1953 patřil tento typ škol vedle gymnázií a učňovských škol do kategorie tzv. výběrových škol III. stupně, přičemž nesly označení odborné a vyšší odborné školy. Teprve až v letech 1953-1960 se oficiálně objevuje označení střední odborné školy. Ty společně s odbornými školami a všeobecně vzdělávacími školami tvořily součást tehdejšího jedenáctiletého středního školství. V dalších letech existence socialistického Československa již toto označení pro tyto školy zůstalo de facto nezměněné, i když se měnila např́ílad struktura vzdělávacího systému. Pro zjednodušení v našem textu, pokud nebude explicitně uvedeno jinak, používáme termín střední odborná škola i pro odborné školy z období let 1948-1953. 
Pro prosazení všech zmíněných úkolů $\mathrm{v}$ oblasti školství přitom KSČ využívala mnohé nástroje. Mohlo se jednat o různé administrativní zásahy v podobě zákonů, vyhlášek, směrnic či výnosů jak z oblasti školství, tak ale i z oblasti hospodářství, kultury a další. Ty v mnoha př́ípadech ovšem vytyčovaly jakési pomyslné mantinely a směr v obecné rovině. Měly dopad zejména na podobu škol a jejich fungování. Na život konkrétního jedince měla v tomto směru dopad až jeho vlastní účast v každodenním chodu těchto škol. Jedním z prvků zmiňovaného každodenního chodu škol v období socialistického Československa bylo, stejně jako dnes, rovněž přijímací ríizení. Administrativní úkon, který výrazným způsobem určuje další profesní i životní kariéru kteréhokoliv uchazeče o studium a ve kterém se v období socialistického Československa v různé míře prolínaly všechny výše zmíněné hlavní úkoly kladené KSČ nejen na střední odborné školy. Např́klad v podobě direktivního rozmist’ování (směrných čísel), komplexního hodnocení či jednání členů přijímací komise v průběhu konání pruijímacího řízení.

Jedná se přitom o problematiku, která je dosud po odborné stránce v podstatě nezpracovaná. $\mathrm{V}$ tomto směru např́klad produkce odborných textů soustředících se na problematiku přijímacího řízení (nejen) na středních odborných školách $\mathrm{v}$ období 50. a 60 . let neuspokojí. Z tohoto období neexistuje $\mathrm{v}$ podstatě žádný odborný text. Pro celá 50. léta bylo navíc typické, že celkově oblast středního odborného školství nebyla vůbec odborně zkoumána, protože po celou tuto dobu chyběla jasně definována úloha odborného školství ve společnosti (Boháč \& Šulcová, 1979). Lze se domnívat, že za tuto skutečnost částečně může i nekritické až slepé napodobování vzdělávacího systému Sovětského svazu a přijímání vzdělávacích reforem pouze na základě usnesení Ústředního výboru KSČ (dále ÚV KSČ) bez širší odborné i veřejné diskuse (př́kladem může být reforma školství z roku 1953, viz Zákon č. 31/1953 a Důvodová zpráva, 1953).

Opravdový mezník podle Boháče a Šulcové (1979) ve vývoji stř̌edního odborného školství, a taktéž první krok k jeho systematičtějšímu výzkumu, nastal až přijetím usnesení ÚV KSČ z dubna 1959 s názvem O těsném spojení školy se životem a o dalším rozvoji výchovy a vzdělání v Československu a na ně navazujícího školského zákona z prosince 1960, kde jsou významným způsobem již reflektovány reálné potřeby československé společnosti. Ke konci roku 1962 navíc začíná fungovat také Výzkumný ústav odborného vzdělávání (VÚOŠ). V kontextu studované problematiky, tedy odborného školství v období socialistického Československa, významná instituce. Zpočátku bylo úkolem tohoto ústavu se soustavně a cílevědomě zabývat problematikou profesní př́pravy na středoškolském stupni, nicméně v průběhu 60. let a zejména na začátku 70. let začal zařazovat do svých plánů taktéž úkoly výzkumné povahy (více viz Švanda, 2000). 
V této souvislosti lze zmínit několik děl, která VÚOŠ prostř̌ednictvím svých pracovníků vydal. Především se jedná o text, který zmiňuje ve své nedávno vydané publikaci zaměřené na odborné vzdělávání a odborné školství na našem území Průcha (2019), od autorů Boháče a Šulcové (1979) s názvem Československé střední odborné školy od osvobození do dneška. Ačkoliv se jedná v současné době asi o nejvýznamnější a zároveň o nejrozsáhlejší dílo z oblasti československého středního odborného školství v období socialismu, a podle Průchy (2019) k československému, respektive českému odbornému školství vůbec, $\mathrm{k}$ průběhu přijímacího řízení na těchto školách ucelenější obraz neposkytuje. VÚOŠ v tomto období vydával řadu různých publikací zaměřených na střední odborné školství ${ }^{2}$. Nicméně, jak se ukázalo, v současné době jsou tyto texty v mnoha př́padech nedostupné. Dủvodem mủže být např́klad fakt, že řada $\mathrm{z}$ nich nikdy nevyšla a existovala pouze ve formě „nerozmnožených manuskriptư“, jak je zřejmé např́íklad z odkazů na literaturu ve výše zmíněném textu Boháče a Šulcové (1979). Mnoho dalších zdrojů, které autoři uvádějí, by mělo sice být publikováno ve větším množství, v katalozích knihoven ${ }^{3}$ České republiky jsou ovšem nedohledatelné.

Pomyslné světlo na konci tunelu může na první pohled představovat publikace od kolektivu autorů Hrabala, Lukše, Pelikána, Šafáře a Váchové s názvem Zpráva z výzkumu přijímacího řízení na střední školy z roku 1976. Tato zpráva, i když se má jednat o „rozmnožený rukopis“ (viz Boháč \& Šulcová, 1979; Linhartová, 1976), není ovšem jako celek v knihovních katalozích opět dohledatelná. V současné době je k dispozici pouze text se stejným názvem z roku 1974 od Jiř́ho Lukše 4 . Ten ovšem dle informací z článku Linhartové (1976) zahrnuje pouze část výzkumu přijímacího rúizení, který byl realizován v letech 1970-1975. V podstatě totožná situace panuje rovněž pro publikace vydané v 80 . letech 20 . století.

2 Švanda (2000) v této souvislosti uvádí, že se jedná o 430 studií a výzkumných zpráv a stovky článků publikovaných v různých odborných časopisech a sbornících.

Autoři při jejich vyhledávání využili katalog Moravské zemské knihovny, katalog Masarykovy univerzity, Mendelovy univerzity v Brně a následně Centrální portál knihoven (bývalá Jednotná informační brána), který v současné době sdružuje knihovní katalogy 47 knihoven nacházejících se na území České republiky (více viz webové stránky portálu: https://www.knihovny.cz/).

${ }^{4} \quad \mathrm{~K}$ dokreslení popisované situace související s dostupností publikací z VÚOŠ může velmi dobře posloužit právě zmiňovaný Lukšův text. Ten byl podle informací uvedených v samotné publikaci vydán celkem ve 330 výtiscích. V České republice je ovšem, na základě dat z Centrálního portálu knihoven, dostupný pouze v pěti knihovnách. Každá vlastní po jednom výtisku. Dohromady je v současné době k dispozici z celkového počtu 330 výtisků pouze 5 kusů. 
Pohled na produkci odborných textů zabývajících se problematikou přijímacího řízení (nejen) na středních odborných školách v letech po sametové revoluci také př́liš nepotěší. Obecně lze totiž konstatovat, že socialistické školství, coby výzkumné téma $\mathrm{v}$ oblasti pedagogických věd, nebylo v porevolučním období př́liš systematicky rozvíjeno. Střední odborné školství $\mathrm{v}$ této souvislosti dosud vůbec. Určitý zájem o téma školství v socialistickém Československu lze vysledovat až na přelomu tisíciletí. V té době byly publikovány první texty např́klad od Václavíka (1997), Vorlíčka (2004), Walterové (2004) či Rýdla (2010). Ačkoliv se jedná o důležité zdroje k poznání školství v socialistickém Československu, jde spíše o přehledové studie, které se snaží vyložit vývoj školství v jednotlivých etapách československého socialistického režimu. O průběhu přijímacího řízení v této době toho až na některé obecné informace mnoho neprozradí.

Systematičtější výzkum problematiky školství v socialistickém Československu se objevuje až v relativně nedávné době. Např́ḱlad v podobě publikace Dany Moree (2013) s názvem Učitelé na vlnách transformace: kultura školy před rokem 1989 a po něm, a zejména pak ve dvou knihách od tria autorů Zounek et al. (2017a; 2017b). Z hlediska řešené problematiky v této studii je zajímavý jejich text s názvem Normální život v nenormální době: základní školy a jejich učitelé (nejen) v období normalizace, kde je ve srovnání s jinými výše zmíněnými zdroji částečně zachycena i problematika přijímacího řízení $\mathrm{v}$ souvislosti s tématem politiky ateizace a jejích projevů na socialistických základních školách (více viz Zounek et al., 2017a).

Bohužel při pohledu do zahraničí lze konstatovat, že ani v tomto směru není situace ohledně zdrojů ke sledovanému tématu zcela př́iznivá. V obecné rovině je téma odborného školství v průběhu 20. století poměrně dobře zpracováno zejména $\mathrm{v}$ př́padech států bez zkušeností se socialistickým režimem, tedy zejména zemí západní Evropy, případně Spojených států amerických, Japonska apod. (nap̌r. Greinert \& Hanf, 2004; Nilsson, 2014; Stenström \& Virolainen, 2014; Wollschläger \& Guggenheim, 2004 ad.). Vzhledem k jinému historickému (v některých případech i kulturnímu) vývoji těchto států jsou $\mathrm{v}$ souvislosti s tímto tématem ovšem nevyužitelné. V př́padech postsocialistických států střední a východní Evropy je situace de facto naprosto stejná jako u nás. Ačkoliv existuje řada publikací věnujících se otázkám socialistického školství (napr. Kestere \& Kalke, 2018; Kudláčová, 2019; Kudláčová \& Šebová, 2019; Mincu, 2016; Rahi-Tamm \& Saleniece, 2016; Somogyváry, 2019 ad.), v podstatě až na výjimky (např. Grootings, 1993; Zajda, 2008) zatím neexistují žádné odborné publikace k tématu odborných škol v socialistických režimech 2 . pol. 20. století, či dokonce studie na tak specifické téma, jako je průběh přijímacího řízení na těchto školách, na který je zaměřen právě náš př́íspěvek. 


\section{Metodologie}

Cílem našeho textu je zachytit průběh přijímacího řízení a jeho proměnu na stř̌edních odborných školách v období socialistického režimu v Československu. Stanovili jsme si přitom hlavní výzkumnou otázku, jakým způsobem se přijímací řízení na středních odborných školách $\mathrm{v}$ průběhu socialistického Československa proměňovalo. Zároveň jsme se ptali i na to, jakým způsobem bylo přijímací ř́zení na tyto školy ovlivňováno tehdejším socialistickým režimem pod vedením KSČ. Respektive jakým způsobem a v jakých zásadních záležitostech (jevech) souvisejících s přijímacím rúizením se tento vliv projevoval. Zaměřujeme se přitom pouze na príijímací rízení uchazečů do denního studia. Takzvané, podle dobové terminologie, mimořádné způsoby studia, jako bylo např. večerní studium, dálkové studium či studium při zaměstnání ad., jsme do naší studie záměrně nezařadili. Důvod je prostý. Zachycení tak komplexní problematiky nelze uskutečnit $\mathrm{v}$ intencích jedné studie. Jednoduše řečeno nelze na tak malém prostoru zachytit všechny detaily, které vycházely ze specifik mimořádných způsobů studia, a koneckonců i uchazečů o některou $z$ forem tohoto studia, jako bylo např. výše zmíněné večerní studium, studium při zaměstnání ad. ${ }^{5}$

Výzkumná data prezentovaná $\mathrm{v}$ této studii jsme získali během první fáze realizace šířeji pojatého výzkumného šetření ${ }^{6}$, které je primárně založeno na historiografickém proudu označovaném jako dějiny každodennosti. Ty lze chápat jako studium životních osudů a širokého rozsahu aktivit v rámci každodenního jednání těch, kteří často stáli za pozadím tzv. velkých událostí či jevů, tedy obyčejných lidí. Jinak řečeno jde o studium rutinních, ale i neočekávaných aktivit často anonymních jednotlivců či skupin lidí, které vedou $\mathrm{k}$ politickým či událostním dějinám, $\mathrm{k}$ tzv. makrohistorii (více např. Eckert \& Jones, 2002). V souvislosti s tématem této studie jde o snahu proniknout do každodenního života středních odborných škol v období socialistického Československa. Prostřednictvím tohoto historiografického př́istupu chceme poznat a pochopit průběh přijímacího řízení realizovaného na těchto školách a také odhalit vliv socialistického zrrízení na jeho průběh.

\footnotetext{
5 Ačkoliv prijiímací řízení probíhalo velice podobně i na jiných typech středních škol, ani $\mathrm{v}$ těchto případech neuvádíme př́ípadné odlišnosti ve srovnání s průběhem přijímacího řízení na středních odborných školách, pokud nebude explicitně uvedeno jinak.

6 Jedná se o projekt s názvem Střední odborná škola v socialistickém Československu pohledem dějin každodennosti. Orálně historické rozhovory s učiteli, financovaný Grantovou agenturou České republiky (číslo projektu 19-24776S) s lety řešení 20192021. Při psaní této studie byl projekt na začátku druhého roku řešení.
} 
Jak podotýká třeba Sedlák (2013) či Otáhal (2002), v souvislosti s výzkumem témat z období komunistické vlády se využití tohoto přístupu jeví jako nanejvýš užitečné, protože doplňuje, rozšiřuje, ale i reviduje obraz komunistické diktatury.

Jakým způsobem ovšem přistoupit ke zkoumání tématu této studie, když, jak ukázal např. výzkum Zounka, Šimáně a Knotové (2017a), dostupnost archivních dokumentů (tradičních zdrojů informací běžných historických výzkumů) z oblasti československého školství pro období let 1948-1989 je z různých důvodů částečně omezená? Jednu z možností, jak zachytit dějiny každodennosti, nabízí metoda orální historie, kterou koneckonců využili ve svém výzkumu i zmínění autoři. Podle Vaňka a Mückeho (2015, s. 14) lze tuto metodu ${ }^{7}$ chápat jako „řadu propracovaných, avšak stále se vyvijejících a dotvářejících postupů, jejichž prostř́ednictvím se badatel v oblasti humanitních a společenských věd dobírá nových poznatků, a to na základě ústního sdělení osob, jež byly účastníky či svědky určité události, procesu nebo doby, které badatel zkoumá, nebo osob, jejichž individuální prožitky, postoje a názory mohou obohatit badatelovo poznání o nich samých, př́padně o zkoumaném problému obecně“.

V rámci orálně-historických rozhovorů s pamětníky (svědky určité události, procesu nebo doby) v podstatě dochází za spoluúčasti jak pamětníka, tak i badatele ke vzniku nového historického pramene, který přináší novou znalost minulosti i nové interpretační perspektivy (Vaňek \& Houda, 2016). Z tohoto úhlu pohledu, jak se domníváme, může metoda orální historie do určité míry zastoupit (nikoliv ale zcela nahradit, jak se ukázalo i v př́padě tohoto textu) úlohu chybějících tradičních archivních materiálů. To je koneckonců i jeden z hlavních důvodů, proč jsme podobně jako výzkumný tým Zounka et al. (2018), kteří stejně jako my narazili na obtížnou dostupnost archivních materiálů, využili metodu orální historie jako jednu z metod našeho výzkumného šetření.

Více informací $\mathrm{k}$ metodě orální historie obecně lze nalézt např́klad v následujících publikacích: Abrams (2016), Janesick (2010), Portelli (2015). Vzhledem k tomu, že specifika metody orální historie ve vztahu k otázkám školství v socialistickém Československu byla poměrně detailně zachycena již v dílech výzkumného kolektivu Zounek, Šimáně a Knotová (např. 2017a; 2017b), v tomto příspěvku se podrobnějším popisem této metody nezabýváme a př́padné zájemce o toto téma odkazujeme na jejich výše zmíněná díla. 
V této souvislosti jsme v naší studii využili data ze 14 rozhovorů ${ }^{8}$ s 6 pamětníky - učiteli/učitelkami, kteří působili na středních odborných školách v bývalém Jihomoravském kraji ${ }^{9}$ minimálně v období socialistického Československa. Narátory byli jeden muž a pět žen. Naši narátoři na středních odborných školách působili převážně v průběhu 70. a 80. let 20. století. Pouze ve dvou př́padech naši pamětníci působili na těchto školách i v 60. letech, respektive na konci 50. let 20. století. Řada pamětníků přitom působila na školách, které sami ve svém mládí absolvovali. Vzhledem k aprobaci se jedná o bývalé (v některých př́ípadech i současné) učitele českého jazyka a dějepisu, ekonomie, účetnictví, psaní na stroji a těsnopisu, uměleckého maliřství, strojírenství či např̀. robotizace a automatizace v průmyslu. Žádný z našich narátorů ve vymezeném období nebyl členem KSČ.

Ve většině př́ípadů jsme s každým narátorem realizovali dva rozhovory. Ve dvou prrípadech se jednalo dokonce o tři rozhovory. Všechny rozhovory byly nahrávány na diktafon a následně doslovně přepsány a anonymizovány, a to nejen $\mathrm{v}$ souvislosti se samotnými narátory, ale $\mathrm{i}$ vzhledem $\mathrm{k}$ údajům o školách a osobách, o kterých se naši pamětníci ve svých vyprávěních zmiňují.

Po přepsání rozhovorů jsme nejprve podrobně a opakovaně pročítali rozhovor, poté jsme prristoupili k tzv. kondenzaci získaných dat (více viz Vaněk \& Mücke, 2015), kdy jsme oddělovali ta sdělení, která se týkala tématu př́spěvku, od těch sdělení, která se vztahovala $\mathrm{k}$ jiným tématům. Následně jsme využili i tzv. indexace přepisu, což je tvorba seznamu jednotlivých prvků rozhovoru, jako jsou data, fakta, specifika narátorova vyprávění ad. Snadněji se nám tak skládala linka celého prŕiběhu, což vedlo k lepšímu pochopení narátorova vyprávění.

Metoda orální historie byla ovšem pouze jednou z metod našeho výzkumu. A to i z toho důvodu, že naši pamětníci působili na středních odborných školách z valné většiny až v průběhu tzv. období normalizace, a vyjadřovali se proto jen $\mathrm{k}$ přijímacímu řízení $\mathrm{v}$ tomto období. To je koneckonců patrné i v naší studii při popisu průběhu přijímacího řízení, kdy data z orálně-historických rozhovorů využíváme převážně právě až v závěrečných částech textu.

8 Celkově jsme dosud realizovali již 21 rozhovorů s 12 narátory. Téma přijímacího řízení nebylo ovšem obsaženo ve všech rozhovorech, př́ípadně získaná data nám nepřišla dostatečně zajímavá (event. se získané informace opakovaly) na to, abychom je použili v této studii. Uvádíme tak celkový počet rozhovorů, ze kterých jsme čerpali data v tomto textu.

9 Vycházíme přitom z územního rozdělení dle zákona z roku 1960. 
Pro zachycení problematiky přijímacího řízení na středních odborných školách i v předchozím období bylo nutné vyhledat proto i další zdroje informací. Z tohoto důvodu jsme tedy metodu orální historie doplnili dále i rozsáhlejším studiem dobové legislativy a některých dobových periodik. $\mathrm{V}$ rámci legislativních norem se jednalo o různé zákony, vyhlášky, směrnice, výnosy, důvodové zprávy $\mathrm{k}$ zákonům apod., ve většině prrípadů z oblasti školství, v některých př́padech z oblasti hospodářství. Jednotlivé zákonné normy jsme přitom vyhledávali zejména ve věstnících ministerstva školstvi $1^{10}$, případně je získali prostřednictvím aplikace ASPI. V rámci dobových časopisů jsme $\mathrm{v}$ souvislosti s tímto tématem využili texty jednak z časopisu s názvem Odborná škola ${ }^{11}$, jednak z časopisu Nová škola ${ }^{12}$. Vyjma ročníků 19-22 (roky 1971-1974) časopisu Odborná škola, které nebyly dostupné, jsme prostudovaly všechny ostatní ročníky obou časopisů.

Při analýze (jak periodického tisku, tak i věstníků ministerstva školství) jsme použili metodu obsahové analýzy, která je speciálně určena pro analyzování obsahu sdělení jakéhokoliv druhu (Disman, 2011). Během analýzy byly jednotkou pozorování otázky přijímacího řízení na středních odborných školách. Záznamovou jednotkou (jednotkou analýzy) byl článek. V uvedených periodikách (respektive věstnících) byly vyhledány všechny články týkající se přijímacího řízení na středních odborných školách, které jsme následně detailně analyzovali.

$\mathrm{V}$ našem textu rovněž $\mathrm{v}$ omezené míře využíváme i některé archivní materiály. Jedná se o materiály z Národního archivu v Praze (z fondu Ministerstva školství z let 1948-1989), které nebyly dosud ještě nikde publikovány a jež vhodným zpo̊sobem doplňují studovanou problematiku. Při studiu archivních materiálů jsme postupovali prostřednictvím tradičních metod historického výzkumu. Využili jsme zejména přímou, případně nepřímou metodu (viz Zounek \& Šimáně, 2014; Zwettler et al., 1996).

10 Názvy věstníků ministerstva školství se v průběhu sledovaného období měnily. Konkrétně jsme tak analyzovali Věstník ministerstva školství a osvěty (1945-1948), Věstník ministerstva školství, věd a umění (1948-1952), Věstník ministerstva školství a osvěty (1953 - pouze několik čísel), Věstník ministerstva školství (1953-1956), Věstník ministerstva školství a kultury (1956-1969), Věstník ministerstva školství a ministerstva kultury a informací (1967-1969), Věstník ministerstva školství a ministerstva kultury České socialistické republiky (1969-1989).

11 Časopis Odborná škola vycházel od roku 1948 až do roku 1990. Přitom v letech 1948-1950 vyšly tři ročníky. Poté bylo jeho vydávání přerušeno. Časopis znovu začal vycházet od roku 1954, přričemž jednotlivé ročníky se začaly číslovat opět od čísla jedna.

12 Časopis Nová škola vycházel pouze v letech 1945 až 1951. Celkově vyšlo jen šest ročníků. 
Analýza dobové legislativy, dobových periodik či některých dostupných archivních materiálů nám při nedostatku sekundární literatury $\mathrm{k}$ tématu výrazným způsobem usnadnila možnost zachytit celkový kontext studované problematiky. Jinými slovy řečeno, poznat téma i z makrohistorického pohledu, bez kterého by zachycení a pochopení průběhu přijímacího řízení na středních odborných školách bylo neúplné.

\section{Nástup}

Pro podobu prìijímacího řízení na středních odborných školách v období socialistického Československa byl určující školský zákon z roku 1948. Ten totiž již obsahoval ideologické myšlenky a požadavky KSČ, které se promítly do různých oblastí každodenního života škol (více viz Zákon č. 95/1948) ${ }^{13}$. Přijímací řízení nebylo přitom výjimkou. Vzhledem $\mathrm{k}$ tomu, že zákon byl přijat pouhé dva měsíce po únorovém puči, některé záležitosti nebyly, jak se brzy ukázalo, zcela dořešené. I přesto se jednalo o výrazný „nástup“ nového směru. Obdobně jako v př́padě hrdinů stejnojmenného budovatelského románu Václava Řezáče $(1951)^{14}$ i prostřednictvím nové podoby přijímacího řízení mělo dojít k vybudování základů pro další rozvoj socialistické společnosti. Nikoliv jen $\mathrm{v}$ malé pohraniční obci, jako tomu bylo ve zmiňovaném románu, ale v celém Československu.

Pokud chceme pochopit podobu přijímacího řízení v prvních a i dalších letech vlády komunistického režimu, je potřeba se nejprve podívat na to, jakým způsobem docházelo $\mathrm{k}$ ukončení povinné školní docházky od přelomu 40. a 50. let do začátku 60. let 20. století.

V této době (vůbec poprvé konkrétně ve školním roce 1950/1951) žáci posledních ročníků zakončovali povinnou školní docházku závěrečnou zkouškou. Jejím účelem bylo zjistit, jaké úrovně uceleného základního vzdělání žák dosáhl, jaká byla ,jeho povšechná rozumová a mravní vyspělost, kterou mu škola do života dala, a jak ho připravila pro budoucí povolání nebo pro další studium“ (Závěrečné zkoušky, 1951, s. 75). Závěrečná zkouška se

13 Jakým způsobem tento zákon (ale i další školské zákony zmiňované v tomto textu) proměnil cíle, obsah vzdělávání či obecně strukturu vzdělávací soustavy, s ohledem na cíle článku nepopisujeme, př́padné zájemce o tuto problematiku si dovolujeme odkázat např. na již v úvodu zmíněné přehledové studie Václavíka (1997), Vorlíčka (2004), Walterové (2004) či Rýdla (2006), případně samostatné znění jednotlivých zákonů.

14 Ve své době představovalo toto dílo pilír socialistické literatury (více viz např. Opelík, 2000). 
přitom skládala z písemné a ústní části a jejich obsahem byl vyučovací jazyk, ruský jazyk, matematika a podle vlastní volby jeden z následujících př̀edmětů: dějepis, fyzika, chemie, př́rodopis. To částečně potvrzuje ve svých vzpomínkách jedna $z$ našich nejstarších narátorek, učitelka účetnictví jedné stř̌ední odborné školy zaměřené na gastronomické a ekonomické služby, Ilona, která v této době ukončovala svou povinnou školní docházku: „... a my jsme končili, dokonce se končilo nějakou, jako malinkou písemkou, si pamatuju, nevím už jak, vím, že něco tam bylo z matiky." Pokoušeli jsme se Ilony doptat na detailnější informace $k$ průběhu závěrečných zkoušek, ale nic dalšího už si v této záležitosti nevybavila, což je zcela pochopitelné s ohledem na to, že od popisované události uběhlo téměř 70 let.

Po provedení klasifikace zkušební komise ${ }^{15}$ postupně pozvala jednotlivé žáky a jejich rodiče $\mathrm{k}$ závěrečnému rozhovoru, kde jim předseda této komise ${ }^{16}$ sdělil výsledek klasifikace. V rozhovoru měl ovšem dále pokračovat zástupce okresního národního výboru - referátu práce a sociální péče, který vyslovil svůj vlastní názor na schopnosti žáka a jeho budoucí uplatnění (Závěrečné zkoušky, 1951).

V úplném závěru tohoto rozhovoru doporučila komise rodičům, aby podepsali, pokud tak ještě neučinili, závaznou přihlášku žáka pro některé povolání nebo přihlášku do některé výběrové školy. $V$ této době ovšem pouze na tzv. odbornou školu, na které nebylo možné získat maturitní vysvědčení opravňující $\mathrm{k}$ přijetí na vysokou školu ${ }^{17}$. Jinak řečeno, úspěšné absolvování závěrečné zkoušky na konci povinné školní docházky žáka neopravňovalo přihlásit se přímo na některou z tzv. vyšších (výběrových) odborných škol ${ }^{18}$, jejichž úspěšné absolvování umožňovalo pokračovat na vysoké škole. Na tyto školy se mohli přihlásit pouze žáci, kteř́ měli jednak úspěšně za sebou výše zmíněnou závěrečnou zkoušku (př́padně rovnocenné školní vzdělání) a zároveň byli vyučeni $\mathrm{v}$ př́íslušném oboru, na který byla vyšší odborná škola zaměřena, př́ípadně měli za sebou minimálně dvouletou praxi, která odpovídala vyučení v př́slušném oboru (Závěrečné zkoušky, 1951). Lze se domnívat, že tento systém přijímacího řízení byl přijat i v sou-

15 Ve složení ředitel školy nebo jeho zástupce, tř́ídní učitel, zástupce okresního národního výboru - referátu práce a sociální péče, zástupce místního národního výboru, zástupce okresní odborové rady a vedoucí pionýrské skupiny na škole, př́ipadně zástupce okresního výboru Československého svazu mládeže (Závěrečné zkoušky, 1951). pracovníků. Bylo přitom pravidlem, že to nebyl nikdo ze školy, kde probíhaly závěrečné zkoušky (Závěrečné zkoušky, 1951).

17 Dnešním ekvivalentem jsou de facto střední odborná učiliště zakončená výučním listem. V podstatě ekvivalent dnešních středních odborných škol. 
vislosti s extenzivním rozvojem hospodářstvív dané době, kdy prioritou bylo, co nejrychleji zajistit pracovníky do jednotlivých oblastí hospodářství socialistického Československa. To koneckonců potvrzují i Boháč a Šulcová (1979) ve svém textu, kteři kriticky píšou, že pro praxi celých 50 . let bylo typické omezování studia, protože plánovací orgány se snažily uspokojovat přednostně potřeby závodů a jiných institucí.

Pro další studium na některé výběrové škole proto komise doporučovala jen ty žáky, kteří při závěrečné zkoušce přesvědčivě prokázali, že mají schopnost samostatně duševně pracovat. Zvlášt' důsledně se navíc přihlíželo $k$ tomu, aby do výběrových škol přicházeli žáci, „kteří svým sociálním a třídním původem, jakož i svým dosavadním vývojem dávají naději, že z nich bude vychována inteligence třídní a ideově spjatá s dělnickou tř́ídou“ (Závěrečné zkoušky, 1951, s. 76). Pokud komise doporučila žáka namísto ke studiu na některé $z$ výběrových škol $\mathrm{k}$ výběru povolání, musela se řídit potřebami tehdejšího plánovaného hospodářství. $V$ tomto směru proto komise doporučovala žákům vybrat si jeden z následujících státem preferovaných oborů: hornictví, hutnictví či strojírenství (Závěrečné zkoušky, 1951).

Po ukončení závěrečných zkoušek ředitel škol uspořádal výsledky žáků podle jednotlivých tř́id a jmenného seznamu žáků. Ke každé složce žáka zároveň připojil doporučení komise a zaslal příslušnému okresnímu národními výboru. Okresní národní výbor (dále ONV) byl rovněž hlavním orgánem, který měl na starosti přijímací řízení na středních odborných školách. Ačkoliv předsedou přijímacího řízení býval zpravidla ředitel dané odborné školy, pouze ONV mělo právo na dané škole zřídit přijímací komisi a vybrat členy této komise. Těmi, kromě ředitele, bývali zástupci různých referátů ONV, členové učitelského sboru dané školy, zástupci podniků a další činitelé, např. z řad Revolučního odborového hnutí (dále ROH), Československého svazu mládeže (dále ČSM) a další (Závěrečné zkoušky, 1951).

Přijímací řízení na střední odborné škole $\mathrm{v}$ této době probíhalo de facto čtyřkolovým systémem. Nejprve totiž uchazeči o studium museli zasílat své přihlášky nejen na ředitelství škol, kam se hlásili, ale společně s žádostí o doporučení ke studiu i k ONV. Pokud ONV žádosti nevyhovělo, přijímací řízení pro uchazeče skončilo. Pokud se jednalo o uchazeče hlásícího se na školu z praxe a ONV žádosti vyhovělo, musel uchazeč o studium přihlášku odevzdat společně s doporučením ONV správě závodu, ve kterém pracoval. Ta v koordinaci s ROH a ČSM doplňovala přihlášku posudkem o uchazeči. Teprve takto vyplněnou přihlášku správa závodu sama odesílala na ředitelství školy, kam se uchazeč hlásil (Závěrečné zkoušky, 1951).

Druhé kolo prrijímacího řízení probíhalo čistě $\mathrm{v}$ dikci prijiímací komise na škole. V podstatě na základě získaných údajů o uchazečích došlo k rozhodnutí, kteří uchazeči splňují či nesplňují podmínky pro přijetí. Odmítnutí uchazeči byli ihned vyrozuměni, a tím pro ně přijímací rízení bylo ukončeno. 
Ti uchazeči, kteří úspěšně prošli i druhým kolem, byli pozváni do třetího. To na středních odborných školách $\mathrm{v}$ dané době probíhalo pouze formou ústního zkoušení - rozhovoru. Rozhovor neměl přesáhnout více než 15 minut a jeho tématem byla látka posledního ročníku základní školy ze společenských nauk, českého jazyka a matematiky (Závěrečné zkoušky, 1951).

Co a jakým způsobem bylo $v$ rámci těchto rozhovorů hodnoceno či jaké otázky byly uchazečům pokládány, prozrazuje dobová zpráva zaměřená na otázku, jakým způsobem se od vydání nového školského zákona vyvinula politická a odborná úroveň absolventů různých typů škol (více viz Mužíková, 1950). Z hlediska našeho tématu je zajímavé sledovat zejména šetření autorky u uchazečů o studium na vyšších hospodářských školách ${ }^{19}$. Autorka totiž při popisu svých zjištění zároveň popisuje i podobu rozhovorů přijímacího řízení. V této souvislosti uvádí, že při těchto vstupních pohovorech (jak je označuje autorka) se hodnotily čtyři základní předpoklady, přičemž každý byl ohodnocen určitým počtem bodů (viz tabulka 1).

Tabulka 1

Oblasti vstupního pohovoru do vy̌ššch odbornjich škol III. stupnè a jejich bodové bodnoty (na základè údaju z Mužíkové, 1950, zpracovali autoři článku)

\begin{tabular}{|c|l|c|}
\hline $\begin{array}{c}\text { Číslo } \\
\text { předpokladu }\end{array}$ & Oblast vstupního pohovoru & Počet bodů \\
\hline 1 & Schopnosti a nadání & 10 \\
\hline 2 & $\begin{array}{l}\text { Politický postoj k lidově demokratické republice, jevící se } \\
\text { zvlášté prací v hnutí pionýrském, event. mládežnickém }\end{array}$ & 4 \\
\hline 3 & Poměr k práci a ke kolektivu & 3 \\
\hline 4 & Účast na budovatelských úkolech & 3 \\
\hline & Maximálně možný celkový počet bodů & 20 \\
\hline
\end{tabular}

Na hodnocení druhého až čtvrtého předpokladu měl přitom významný vliv posudek školy, kterou uchazeči o studium na vyšší hospodářské škole absolvovali. Jak sama autorka (Mužíková, 1950) trochu jinými slovy dodává, v této fázi přijímacího řízení vlastně neexistovali uchazeči, kteří by v tomto směru nevyhovovali. Jinak řečeno, byli „vyfiltrováni““ již v dřívějších kolech. A to výše uvedeným způsobem, tedy bud' zamítavým rozhodnutím ONV, nebo zamítnutím $v$ rámci přijímací komise na dané škole. Během rozhovoru se hodnotil de facto pouze první předpoklad - schopnosti a nadání, a to

19 Dnešním ekvivalentem by byla nap̌r. obchodní akademie či ekonomické lyceum. 
zejména prostřednictvím otázek zaměřených na společenské nauky. Vyučovací jazyk a matematika byly upozaděny. $V$ tomto směru prijímací komise pokládala např́ílad otázky k tématům: „hospodářství prvotně pospolité společnosti, Marx a Engels, Význam ř́́jnové revoluce, Pomoc venkovu, Národní fronta, Jak dosáhneme vyšší produktivity práce, 14. a 28. ř́jen, Slovenské povstání, Práva občanů naší lidově demokratické společnosti a jinéc (Mužíková, 1950, s. 268).

Po tomto rozhovoru přijímací komise připravovala z úspěšných uchazečů návrh k přijetí vybraných žáků. Ten byl posléze postoupen krajskému národnímu výboru (dále $\mathrm{KNV}$ ), který tvořil poslední instanci v rámci přijímacího řízení, jinými slovy řečeno, představoval čtvrté závěrečné kolo celého řízení. Při každém KNV v tomto směru byla vytvořena také výběrová komise, jejímiž členy byl v pozici předsedy referent pro školství, osvětu a tělesnou výchovu, nebo jeho zástupce a dále zástupci jednotlivých referátů KNV, prrípadně další činitelé. Jednání komise se účastnili rovněž jednotliví ředitelé středních odborných škol v rámci daného kraje. Komise KNV za jejich účasti rozhodovala s konečnou platností o přijetí či nepřijetí žáků do jednotlivých středních odborných škol v kraji, o kterém následně ředitelé informovali jednotlivé uchazeče.

Při svém rozhodování přitom výběrová komise KNV kontrolovala např́klad i to, zda komise zrrízené na středních odborných školách v rámci prijiímacího ř́izení při finálním výběru uchazečů (tedy po realizaci rozhovoru) přihlíží i $\mathrm{k}$ předem naplánovanému počtu míst, která bylo možné na dané škole novými žáky obsadit (Závěrečné zkoušky, 1951). Tato stručná, velmi lehce přehlédnutelná poznámka $\mathrm{v}$ jinak poměrně rozsáhlém výnosu ministerstva školství představuje jeden $\mathrm{z}$ dalších zásadních momentů typických pro prrijímací řízení v období socialistického Československa. Tento jakýsi kvótní výběr (viz Simonová, 2011; Kreidl, 2008), dobovou terminologií direktivní rozmíst’ování (od 60. let pod pojmem směrná čísla) bylo jinak řečeno zavedeno v situaci, kdy požadavky podniků a hospodářských resortů na počty absolventů byly značně vyšší než možnosti škol. Plány rozmístování byly přitom realizovány centrálně $\mathrm{v}$ př́slušných ministerstvech, a to podle celkového rozpisu ze Státního úrúadu plánovacího (Boháč \& Šulcová, 1979). Jednalo se opět o důsledek plánovaného hospodářství a potřeby zajistit požadované množství pracovníků do vybraných oblastí hospodářství.

Rozmístování se přitom týkalo nejen studia na středních odborných školách, ale i dalších typů středních a zejména vysokých škol (více viz např. Vládní nařízení 2/1952 Sb, 1952). V této souvislosti jsou zajímavá slova Alana, který vypráví o svých zkušenostech ze střední umělecké školy, kterou v období socialismu navštěvoval: „Za té totality byla situace taková, že se brali z celé republiky, to bylo zajímavý, od Plzně, jeden byl z Plzně a jeden byl z Michalovců a mezitím byli všichni ty ostatní, takže třeba těch Brňáků tam 
ani moc nebylo, protože byly nějaký směrný čísla, který se musely dodržovat.“ Jak velmi dobře postřehl, direktivní rozmístování (směrná čísla v Alanově podání) bylo na středních odborných školách stanoveno i geograficky. Nebylo tedy nezvyklé, že na školu se přijímali žáci z různých „koutư Československé republiky, tedy že např́klad v Brně studovali na střední odborné škole žáci z Plzně či až ze vzdálených slovenských Michalovců. Jedním z důvodů byla skutečnost, že výstavba školních budov neodpovídala růstu počtu žáků; zejména pak v případě Slovenska (Historická statistická ročenka ČSSR, 1985). Jiným důvodem mohlo být, jak nepřímo poukazují Boháč a Šulcová (1979) ve své publikaci, že po úspěšném absolvování dané školy bude absolvent vrácen (opět direktivně, např. prostřednictvím umístěnky) zpět do místa svého bydliště, aby vypomohl v daném oboru. Jinak řečeno zajistit pracovní sílu i v méně přitažlivých závodech, zejména pak v pohraničních či venkovských oblastech (viz také v této souvislosti Kučerová et al., 2020).

\section{Ustálení systému}

Nastavený systém přiijímacího řízení v prvních letech komunistického režimu platil v období po vydání nového školského zákona v roce 1953, tedy po celá 50. léta 20. století. Došlo jen k drobným změnám v organizaci podávání přihlášek a průběhu přijímacího řízení. Jednou z nich bylo např́iklad přijímání žáků na střední odborné školy bez zkoušky. Důvodem byla skutečnost, že se v jednotlivých oborech i na různých odborných školách projevil nestejný zájem o studium ze strany uchazečů. $Z$ tohoto důvodu bylo rozhodnuto, že tam, kde počet uchazečů nepřekročil plánem stanovený počet, vyloučila přijímací komise na základě písemných podkladů nevhodné uchazeče a ostatní přijala bez zkoušky. $V$ př́padech, kde počet uchazečů i po vyloučení nevhodných uchazečů byl stále vyšší, než stanovoval plán, se zkouška, formou rozhovoru, konala nadále (K novému způsobu, 1957).

$\mathrm{K}$ některým výraznějším změnám došlo až s přijetím dalšího školského zákona v roce 1960. Ve stejný rok, kdy vyšla i nová ústava československého státu, ve kterém bylo již zakotveno, že se jedná o socialistickou republiku. Ačkoliv byl tento nový školský zákon přijat v období, kdy celý východní socialistický blok v důsledku odhalení zločinů Stalina na XX. sjezdu Komunistické strany Sovětského svazu procházel částečným uvolněním režimu, a i KSČ ve své politice upustila od slepého následování Sovětského svazu ${ }^{20}$, neznamenalo to ovšem, že by upustila od ideologie marxismu-leninismu

20 Více k tématu kritiky kultu osobnosti Stalina (např. Swain \& Swain, 1998; Smith, 2017b). 
a svých základních kritérií, která stanovila např. i pro přjijimací řízení na střední odborné školy v předchozích letech. Naprríklad ke studiu na středních odborných školách se podle nové vyhlášky upravující podobu přjímacího řízení měly stále přijímat „schopné děti z třídně a politicky uvědomělých rodin, které se aktivně zúčastňují práce na dovršení výstavby socialismu“ (Přijímání uchazečů, 1961, s. 17). Zohlednila se de facto pouze skutečnost, že republika již byla prohlášena za socialistickou. Stejně tak zůstalo beze změny např́íklad přednostní přijímání uchazečů hlásících se z pohraničních oblastí, vliv národních výborů, direktivní rozmíst’ování (v této době již pod pojmem směrná čísla) ad.

Zásadní změnou bylo zjednodušení celého procesu. V první řadě vliv ONV či KNV ve věci organizace prrijímacího řízení nebyl již tak silný jako v př́padě 50. let 20. století. Celé rúzení bylo mnohem více v gesci samotných škol. Ovšem i nadále bylo ONV či KNV zastoupeno přímo prostřednictvím svých zástupců jako členů jednotlivých přijímacích komisí (více viz Přijímání uchazečů, 1961; Směrnice pro rozmist’ování mládeže, 1962; Směrnice pro rozmist'ování mládeže - změna, 1962; Směrnice pro rozmist'ování mládeže, 1965 ad.). Na základní škole již taktéž neprobíhaly závěrečné zkoušky. Nicméně i přesto na nich $\mathrm{v}$ trochu jiné variantě ve srovnání s předchozími roky probíhalo jakési první kolo přijímacího řízení. Na školách totiž byly zřízeny „přijímacíc komise ${ }^{21}$ (v pozdějších letech označované jako tzv. rozmíst’ovací komise, viz Směrnice pro rozmist’ování mládeže, 1962), které rozhodovaly o výběru žáka ke studiu na střední škole. Hlavní úlohu v tomto směru měl třídní učitel. Ten musel zhodnotit všechny předpoklady jednotlivých žáků a připravit posudek na žáka, v této době již označovaný jako tzv. komplexní hodnocení. Nejednalo se přitom jen o odborné předpoklady žáka či jeho zájem o studium, ale zejména o jeho tzv. třídní a politické předpoklady. Komplexní hodnocení bylo nejdůležitějším dokumentem v této fázi přijímacího řízení. Komise na úrovni základní školy totiž na jeho základě rozhodovala o doporučení či nedoporučení ke studiu (Směrnice pro rozmist’ování mládeže, 1962).

21 Předsedou komise byl již ředitel školy, nikoliv pracovník pověřený ONV jako v 50. letech 20. století. ONV v tomto směru bylo zastoupeno v podobě jednoho z dalších členů této komise. Nově (ve srovnání s předchozími lety) př́ibyl zástupce Sdružení rodičů a přátel školy. Dále byly členy komise i zástupce školské organizace ČSM, tř́ídní učitel a dva další zkušení učitelé vyučující ve třídě, z níž pocházel uchazeč (Přijímání uchazečů, 1961). V dalších letech v souvislosti se zavedením výchovných poradců do škol byl členem této komise i výchovný poradce školy, na kterého přešly některé úkoly, jež do té doby zastával tř́́dní učitel, např́íklad rozhovor s rodiči žáků o výběru povolání apod. $V$ pozdějších letech byl členem této komise dále nap̌r. i zástupce místního národního výboru a zástupce odborového svazu zaměstnanců školství a kultury (viz Směrnice pro rozmist’ování mládeže, 1962). 
V této souvislosti vzpomíná např́klad učitelka odborných předmětů Olga, která působila na střední odborné škole zaměřené na strojírenství: „...pokud ten tř́ídní byl rozumnej, tak to psal tak všeobecně, jak se jeví v těch předmětech jednotlivých, no a pak samozřejmě pokud tam měl někdo škraloup, tak to se tam prostě muselo napsat. Jo, to byl ten problém, že když teda rodič udělal něco prostě, co se nelíbilo tehdejšímu režimu, tak to tam prostě muselo být napsaný, a to děcko tím pádem mělo uzavřený ty cesty jako dál. To tam prostě muselo být, protože ten třídní by za to dostal jako docela po šlapkách.“Z její výpovědi je zřejmé, že součástí hodnocení byl nejenom žák, ale i rodiče žáka. Záleželo proto především na prrístupu samotného třídního vyučujícího, jakým zpơsobem toto komplexní hodnocení sepíše. Pokud jeho záměrem bylo např́klad dítěti „neublížit“, mohl hodnocení formulovat obecně, ale s rizikem př́padného postihu, pokud záměrně zamlčel některé skutečnosti, které nebyly v souladu s tehdejší ideologií KSČ. V tomto směru je nutné si uvědomit, že o žákovi (potažmo i jeho rodičích) mohli mít detailnějšś informace i jiní členové komise. Např́íklad další učitelé, kteří se s žákem vídali během výuky. „Pozapomenutí" na některé „škraloupy“ tak mohlo být velmi lehce odhaleno a mohlo přinést neblahé důsledky, jak koneckonců popsali v rámci jednoho prŕkladu ve svém textu naprŕíklad i Zounek a kolegové (2017a).

Pokud komise rozhodla kladně, musela vypracovat ve spolupráci s učitelským sborem podrobný posudek, který připojila k přihlášce ke studiu žáka. Sama si následně tuto přihlášku ještě doplňovala dalšími údaji, jako bylo např́iklad vyjádření z místa bydlišsě, popřípadě pracoviště rodičủ žáka. Jednoduše tak, aby přihláška poskytovala ucelený obraz uchazeče a jeho rodinného prostředí. Veškerou dokumentaci následně ředitel základní školy zaslal na ředitelství stř̌ední školy, kam se žák hlásil. Přihlášku ke studiu na střední odbornou školu přitom žák již před zahájením řízení této komise doporučil přímo řediteli základní školy, na které absolvoval svou povinnou školní docházku (Zounek et al., 2017a).

Druhé a třetí kolo přijímacího řízení probíhalo již čistě v gesci střední odborné školy. K tomuto účelu sloužily opět přijímací komise. Stejně jako na základní škole, a i v předchozím období, byl jejím předsedou ředitel školy. Dalšími členy byl zástupce KNV (v př́ípadě jiných než středních odborných škol se jednalo o zástupce ONV), zástupce výboru školské organizace ČSM, tři další zkušení učitelé školy, pokud možno z řad učitelů odborných předmětů, zástupce $\mathrm{ROH}$, doporučený krajskou nebo okresní odborovou radou, a nově, ve srovnání s podobou přijímacího řízení v 50. letech 20. století, vybraný učitel základní školy. Komise v první řadě vyhodnotila dokumenty, které jí zaslali ředitelé jednotlivých základních škol. Na jejich základě rozhodla o tom, kteří z uchazečů budou vybráni. Pro přijetí se musela vyjádřit většina členů komise. Vznikl-li v takovéto fázi rozpor např́ḱlad mezi názorem 
zástupce KNV a ostatních členů, nebo ředitele školy jako předsedy komise a ostatními členy komise, musel být takovýto př́pad předán komisi KNV, která rozhodla s konečnou platností (Zounek et al., 2017a). V této souvislosti je dobré upozornit, že na podobné situace legislativní dokumenty k přijímacímu rúzení z 50. let 20. století vůbec nemyslely, přitom se lze domnívat, že k podobným rozporům docházelo i tehdy.

V této době měli větší zastání i rodiče dětí, kteří nesouhlasili s rozhodnutím komise, at' už na základní či střední odborné škole. V př́padě nesouhlasu se mohli odvolat k ONV (pokud nesouhlasili s rozhodnutím komise základní školy), respektive KNV (v případě nesouhlasu s rozhodnutím komise na střední odborné škole), která jejich žádost prošetřila. Je dosud neobjasněnou otázkou, jakým způsobem tyto orgány dále v těchto záležitostech rozhodovaly. Nicméně, i v tomto př́padě lze sledovat určitý posun ve srovnání s předchozími lety, kdy v případě nesouhlasu rodičů s rozhodnutím komise (např. ve věci doporučení ke studiu) doslova stálo, že ,je komise o správnosti svého doporučení přesvědčí“" (Závěrečné zkoušky, 1951, s. 76). Jakým způsobem takové přesvědčování probíhalo, se lze ovšem při nedostatku relevantních pramenů jen domnívat.

Toto druhé kolo přijímacího řízení na stř̌edních odborných školách končilo výběrem vhodných uchazečů a sestavením pořadí přihlášených uchazečů. Přesáhl-li počet přihlášených uchazečů plánovaný počet žáků, kteří mohli být na školu přijati, zaslal ředitel střední školy veškerou dokumentaci přebývajících žáků ihned těm školám, které byly uvedeny na druhém místě přihlášky uchazeče (Směrnice pro rozmist’ování mládeže, 1962). Jednalo se o další významnou změnu ve srovnání s předchozími lety. Přijímací řízení pro žáka $\mathrm{v}$ tomto prŕpadě totiž nekončilo, ale $\mathrm{v}$ podobných intencích pokračovalo na druhé zvolené škole. Pokud ani na této škole neuspěl, byl mu doporučen učební nebo pracovní poměr a možnost studia $\mathrm{v}$ dalších letech (Směrnice pro rozmist'ování mládeže, 1962).

Závěrečné třetí kolo poté probíhalo obdobně jako v 50. letech 20. století prostřednictvím ústní zkoušky - pohovorem ${ }^{22}$. K pohovoru si uchazeč musel donést pouze vysvědčení z prvního pololetí posledního ročníku základní školy a žákovskou knížku. Obdobně bylo v rámci pohovoru přihlíženo zejména na posudek (komplexní hodnocení, které bylo zasláno základní školou

22 Od druhé poloviny 60. let přibyla i písemná část, která byla zaměřena na vyučovací jazyk a matematiku. Ústní část poté následovala pouze v př́padech, kdy přijímací komise zjistila výrazný rozpor mezi výsledky písemné přijímací zkoušky a prospěchem uchazeče a jeho komplexním hodnocením (Směrnice pro rozmist’ování mládeže, 1965 ad.). 
společně s ostatními dokumenty). Na základě výsledků těchto pohovorů byli komisí na střední odborné škole vybráni nejvhodnější uchazeči a tím bylo de facto celé prrijímací ŕízení uzavřeno. Komise již nemusela zasílat výsledky přijímacího řízení na další schvalování ke KNV jako v předchozích letech. $\mathrm{V}$ tomto směru bylo prostřednictvím svého zástupce $\mathrm{v}$ komisi KNV informováno pouze o obecném průběhu přijímacího rúzení a prrípadných sporných př́padech (Směrnice pro rozmist’ování mládeže, 1962).

\section{Bez stranické kontroly}

Podoba přijímacího řízení zůstávala $\mathrm{v}$ podstatě stejná až do sametové revoluce $\mathrm{v}$ roce 1989. Významnou výjimku v tomto směru tvoří pouze roky kolem tzv. pražského jara, kdy došlo k výraznému uvolnění politického režimu a v řadě oblastech společnosti docházelo k pozvolným demokratickým reformám. Školství nebylo výjimkou, jak dokazuje např́iklad text Zounka, Šimáně a Knotové (2018). Události pražského jara měly své projevy i v podobě přijímacího řízení.

V této souvislosti je zajímavé sledovat, jak ve směrnicích z roku 1967 a 1968 ubývá ideologický rozměr celého přijímacího řízení i kontrola ze strany orgánů KSČ. Např́iklad ve Směrnici pro přijímání ke studiu z roku 1967 již není žádná informace o tom, že by žáci měli být vybíráni na základě svého sociálního postavení, tedy že by měli být vybíráni přednostně uchazeči z řad dělníků a rolníků, nebo podle směrných čísel. Naopak podle této směrnice „střední škola pozve k přijímací zkoušce všechny uchazeče o studium na středních školách, kteří úspěšně dokončili devátý ročník“ základní školy (Směrnice pro přijímání ke studiu, 1967, s. 135). Role KNV byla zcela upozaděna. Tento rok pouze zajišt’ovala jednotný postup při stanovování zkušebních otázek a jejich obsahu, a to navíc podle metodických pokynů vydaných ministerstvem školství. Samotné zkušební otázky si nicméně připravovali ředitelé škol již sami, a to na základě učební látky probírané na základních školách.

Jednou z mála záležitostí, která přetrvala i v tomto roce a jež hrála pravděpodobně stále určitou roli, bylo komplexní hodnocení (Směrnice pro přijímání ke studiu, 1967). Jaký význam byl tomuto hodnocení během přijímacího řízení v této době připisován, ovšem nelze na základě našich zdrojů přesně určit. Jisté je, že s komplexním hodnocením se již vůbec nepočítalo u príijímacího řízení v roce 1968 a ani v roce následujícím (viz Prozatímní směrnice, 1968). Je možné, že k tomuto rozhodnutí došlo i na základě podobné žádosti, jako byla žádost adresovaná ministerstvu školství ředitelem jedné ze základních škol v Uherském Brodě, který píše: „Výnos o komplexním hodnocení žáků byl od samého počátku nevhodný. Mnoho slov o ničem! 
Málokterý učitel měl tu odvahu napsat o žákovi skutečnou pravdu. Narazil na odpor rodičů, a u rodičů-funkcionářů to bývala hotová pohroma. Učitel to na své kůži často pocítil. Vysvědčení by mělo rozhodně stačit (...) V př́ípadě, že se bude i nadále komplexní hodnocení jako charakteristika žáka psát, navrhujeme, aby bylo co nejstručnější, neformální, výstižné, a psát je pouze $\mathrm{v}$ tom případě, kde je nutné, kde se chce něco důležitého o žákovi sdělit“ (Připomínky k některým školským otázkám, 1968, n. s.).

K přijímacímu řízení ke studiu na středních odborných školách byli v této době prijímáni bez výjimky všichni žáci pouze na základě svých schopností a zájmů. Jejich ideologické předpoklady již nehrály žádnou roli. Žáky přitom přijímal ředitel střední odborné školy podle doporučení tř́í- až pětičlenné komise, kterou sám zřizoval. Ta se skládala pouze z učitelů dané školy. Předseda byl jmenován ředitelem školy z řad členů komise (Prozatímní směrnice, 1968). Součástí komise již nebyl žádný funkcionář ONV, KNV či zástupce ROH, ČSM apod., pokud takovou funkci shodou okolností nezastával některý ze členů komise - učitelů dané školy. Komunistická strana sehrávala svou úlohu opět pouze prostřednictvím KNV, které dohlíželo na jednotný postup při stanovování zkušebních otázek a jejich obsahu.

Samotné přijímací řízení probíhalo následovně. Žák v posledním ročníku základní školy vyplnil přihlášku k přijímacímu řízení na střední školu, kde doplnil dvě školy podle svých preferencí. Vše probíhalo bez jakéhokoliv doporučování ze strany rozmíst'ovací či podobné komise. Ta v této době na základní škole ani neexistovala. Přihlášku žák dodal řediteli základní školy, který ji opatřil svým stanoviskem a posudkem lékaře o zdraví žáka a následně zaslal ředitelství střední odborné školy. V daný čas se uchazeči o studium na střední škole dostavili k písemné přijímací zkoušce, která se konala z vyučovacího jazyka a matematiky. $\mathrm{V}$ tomto směru se nic neměnilo. Změna nastala ovšem u ústní zkoušky, ke které docházelo pouze v případech, kdy komise narazila na zásadní rozpor mezi výsledkem písemné přijímací zkoušky a prospěchem uchazeče na základní škole. V takovýchto prrípadech na rozdíl od předchozích let již vůbec nehrála roli komplexní hodnocení. Přijímací řízení bylo následně ukončeno tím, že uchazeči byli informováni o úspěchu či neúspěchu, a dokumentace z přijímacího řízení byla uložena v archivu školy (více viz Prozatímní směrnice, 1968).

\section{Návrat „spolehlivých“ funkcionářů}

Invaze vojsk Varšavské smlouvy v srpnu roku 1968 ovšem předznamenala další vývoj i v oblasti prrijímacího řízení na střední odborné školy. Nepřekvapí proto, že téměř okamžitě došlo k návratu k systému, který na školách fungoval před rokem 1967. Do přijímacího řízení se „,v plné síle“ vrátila např. jeho 
ideologická rovina. Ve srovnání s první polovinou 60. let 20. století byla dokonce mnohem více zdůrazněna. Během přijímacího řízení proto opět měl být kladen silný důraz na tř́ídní a sociální skladbu naší socialistické společnosti a úměrně $\mathrm{k}$ tomu zabezpečovat sociální skladbu žáků přijímaných na stř̌ední školy, zejména vytvářet podmínky pro plné uplatnění nadaných dětí $\mathrm{z}$ rodin dělníků a družstevních rolníků (...) přihlížet k potřebám hospodářských odvětví, daným nerovnoměrným územním rozmístěním s cílem co nejúčinnějšího využívání absolventů středních škol (...) podle stanoveného státního plánu rozvoje národního hospodářství... (Směrnice o přijímání ke studiu, 1970, s. 21-22).

Do „hry“ se vrátily i tzv. rozmíst’ovací komise zřizované na základních školách i komplexní hodnocení, která hrála $\mathrm{v}$ rámci přijímacího řízení stejnou úlohu jako v letech před pražským jarem. Jeho znovuzavedení v plné podobě, jako $\mathrm{v}$ předchozích letech, bylo ovšem pozvolné. Svědčí o tom několik archivních dokumentů. Např. zmínka, „že jedním z nedostatků přijímacího řízení v roce 1971 byla slabá úroveň komplexního hodnocení uchazečů, vypracovaná základními školami“, což zčásti „bylo zaviněno tím, že metodické pokyny ke směrnicím o přijímání ke studiu nemohly být v roce 1971 pro nedostatek času důkladněji propracovány" (Metodický pokyn pro vypracování, 1971, n. s.). Tvorba metodického pokynu se ovšem také nedařila podle představ odpovědných funkcionářů KSČ, jak dokazuje jiný dokument: „Metodický návod ke komplexnímu hodnocení žáků končících povinnou školní docházku (...) je koncipován jako návrh k vedení pedagogické dokumentace o žácích a pro účely (...) se nehodí“ (Metodický pokyn ke komplexnímu hodnocení, 1971, n. s.). Dá se proto předpokládat, že v prvních letech normalizace bylo přijímání uchazečů na střední odborné školy méně zatíženo ideologickými požadavky na uchazeče než v době tzv. „tuhé" normalizace (tj. zhruba na přelomu 70. a 80. let 20. století) a přijímací komise se více soustředily na úroveň vzdělání jednotlivých uchazečů. To koresponduje i s vyprávěním Lady, která absolvovala přijímací řízení na střední průmyslovou školu v roce 1972: „Základ byla matika a čeština. Ta zkouška byla poměrně tvrdá jo. To znamená, jako byly tam slovní př́ílady a těžký, nebylo to jako jednoduchý, bylo to jako poměrně hodně složitý ty př́klady, byly jako na podstatně vyšší úrovni než ted'ka jo, a v podstatě potom přišly výsledky.“

Samotný průběh přijímací zkoušky, její hodnocení, informování žáků o úspěchu či neúspěchu, byl totožný jako v letech před pražským jarem. Ředitelé dokonce přišli o možnost tvořit témata přijímacích zkoušek. Tato kompetence po roce 1968 zcela připadla prúílušnému KNV (více viz Směrnice o přijímání ke studiu, 1970; Směrnice, jimiž se mění a doplňuje směrnice, 1971).

Přestože se do přijímacího řízení vrátily výše popsané momenty, některé záležitosti uvedené v život v letech 1967 a 1968 v určité míře a s menšími odlišnostmi překvapivě přetrvaly. Např́íklad velikost a částečně i složení 
přijímací komise na středních školách. Komise mohla být maximálně pětičlenná a její složení určoval ředitel školy, který byl nicméně v této době již i jejím předsedou. Členy komise byli dále vedle ředitele zkušení učitelé dané školy, ke kterým nově přibyl pouze zástupce stanovený krajským výborem Národní fronty (ibid). Zastoupení funkcionářů KSČ bylo o poznání „slabší“ než v letech před pražským jarem. V této souvislosti je nutné si ovšem uvědomit, že během normalizace i na pozicích ředitelů středních odborných škol působily osoby, které, jak popisují ve svém textu v souvislosti s čistkami na základních školách Zounek a kolegové (2017a), zastávaly během pražského jara „správná“ stanoviska. Byly proto v mnoha př́padech z pohledu tehdejšího režimu již prověřené a spolehlivé. Jako členy komise si tedy tito ředitelé velmi pravděpodobně vybírali rovněž stejně prověřené a spolehlivé kolegy $z$ řad učitelského sboru dané školy.

V této souvislosti je zajímavé sledovat vyprávění některých našich pamětníků, kteří vzpomínají na činnost ředitele během přijímacího řízení v tehdejší době. Ačkoliv se na jednu stranu řídili pravidly, která byla stanovena politickými a hospodářskými potřebami státu, na druhou stranu zároveň sledovali i své potřeby. To byl třeba př́ipad i jednoho ředitele střední odborné školy, která se zaměřovala na gastronomické a ekonomické služby a dodnes sídlí v jednom menším městě bývalého Jihomoravského kraje. Jak vzpomíná např. Rita, učitelka na tamější škole: „Taky dělal jednu věc. Představte si, že on chtěl, několik let o to usiloval, že bude dělat talentové zkoušky, aby byly pěkný děvčata. On nechtěl nějakou, nějakou škaredou. On chtěl pěkný děvčata... No a ono to neprošlo." Cílem ředitele bylo během přijímacího řízení vybrat uchazečky nikoliv na základě výše popsaného způsobu výběru uchazečů, ale čistě podle vlastního subjektivního názoru na vzhled uchazečky. Ačkoliv by sice s velkou pravděpodobností v takovýchto př́ípadech ignoroval např. i komplexní hodnocení uchazečů (což by mohlo mít pozitivní dopady pro některé uchazeče), lze i přesto konstatovat, že se jedná o pochybný průběh přijímacího řízení a je jen stěží omluvitelný. A to koneckonců i vzhledem $\mathrm{k}$ hlavnímu důvodu, který ředitele k takovému jednání vedl a který prozrazuje Rita: „Von potřeboval reklamu školy, aby mu řekli, Ondřeji, ty tam máš pěkný holky.“ Aby získal pro své záměry alespoň částečně legální oporu, usiloval o zavedení talentových zkoušek. Jak podotýká Rita, to mu neprošlo. Důvodem byla skutečnost, že na tomto typu škol nebylo možné talentové zkoušky konat, ty byly určeny jen pro některé střední školy, jako byly např́iklad střední umělecké školy či konzervatoře (viz např. Směrnice o přijímání ke studiu, 1970).

Ředitel se ovšem svého záměru nevzdal a plně využil veškeré své pravomoci, které získal jako předseda prijímací komise. V první řadě do komise jmenoval učitele, jejichž loajalitou ke své osobě si byl zcela jist. Dokládá to následující tvrzení Rity: „On prostě měl lidi, který měli být přijati, tak udělal 
komis (...) a systém fungoval díky tomu, že byl obklopen skupinou učitelů, kteří jej uznávali a glorifikovali. U kterých si nebyl jist postojem k němu či k situaci, tak ty svými úkoly neobtěžoval.“ Následně během přijímacího ř́izení, jak dále dodává naše narátorka: „...chodil po těch tř́ídách, jak se psaly písemky, a vokukoval, a když viděl pěknou holku, tak se podíval, jaký má číslo [namísto jména a př́ijmení se při písemných zkouškách uváděl číselný kód - poznámka autoři], a napsal si to číslo na papírek, poznačil si ho.“ Následně do tohoto způsobu výběru uchazeček zapojil i další členy přijímací komise $\mathrm{z}$ řad učitelského sboru dané školy. $\mathrm{V}$ podstatě velice jednoduše: „On prostě těm svejm oblíbenejm [učitelům - poznámka autorů] dal čísla, kódy, který mají opravit dobře. No tak oni to tam dopsali a vopravili (...) ti učitelé to opravili těm žákům a voni dostali body a dostali se." Řediteli loajální učitelé (členové komise) proto na základě výběru ředitele museli v př́ipadě potřeby doplnit písemné práce uchazeček a opravit tím zpưsobem, aby bylo jisté, že budou na školu přijaty.

V této souvislosti se nabízí ovšem otázka, jak na celou záležitost nahlížel poslední člen pryijímací komise, a to zástupce stanovený krajským výborem Národní fronty, který nebyl součástí učitelského sboru dané školy. To opět prozrazuje vzpomínka Rity: „Von to měl prošpekulovaný. Tohleto měl nachystaný. Kontakty, styky, známosti. On se dostal do nomenklatury, dělal to, co oni chtěli slyšet, a maximálně jim vyšel vstříc a oni z něho měli a on z nich.“ Jednalo se tak o oboustranně výhodný vztah. Pro doplnění dodáváme, že tyto styky se stranickými funkcionáři ředitel budoval kromě jiného prostřednictvím takto vybraných uchazeček. Konkrétně např́klad „obsluhovaly na OV [okresním výboru - poznámka autorů], ony obsluhovaly na okresních konferencích" (Rita). Při těchto př́ležitostech, jak naše pamětnice dále vzpomíná, „ř́ikal ředitel těm holkám: ,když obsluhuješ, tak se jim přitlač prsama na záda““. Budování vztahů mezi ředitelem a okresními či krajskými funkcionáři strany bylo minimálně $\mathrm{v}$ těchto př́padech založeno na nevybíravých způsobech zneužívání žákyň střední odborné školy, kterou ředitel vedl.

Systém přijímacího řízení na středních odborných školách ve výše popsané podobě de facto přetrval až do konce samotného socialistického režimu. Legislativní změny přijaté $\mathrm{v}$ souvislosti se zásahy ve školství v roce 1978 či $\mathrm{v}$ důsledku reformy školství v roce 1984 se do podoby přijímacího řízení promítly jen nepatrně. Svědčí o tom i vzpomínka Kláry, která v průběhu 80. let působila jako učitelka češtiny a dějepisu na jedné stř̌ední průmyslové škole a jako členka prijiímací komise měla na starosti prrípravu písemné zkoušky z vyučovacího jazyka: „Přijímačky jsme připravovali vždycky v rámci komise. To se nic nezměnilo ani po tom [po roce 1989 - poznámka autorů], to je změna až ted’ pár posledních let. Vždycky se připravil nějakej diktát, rozbor, dali jsme to dohromady, obodovali jsme si to, a pak to teda ty děcka dostaly a my jsme to opravili.“ 
Jak prozrazují další směrnice získané z věstníků ministerstva školství, jednalo se pouze o dílčí úpravy v důsledku změn názvů různých orgánů KSČ či názvů některých stěžejních dokumentů přijímacího řízení. Např́klad počátkem 80 . let se z dokumentů vytrácí tzv. komplexní hodnocení, avšak pouze $\mathrm{v}$ podobě názvu. Jak ukazuje např́ílad jeden $\mathrm{z}$ archivních materiálů, komplexní hodnocení nahradil dokument s názvem Osobní charakteristika žáka. Ten přitom obsahoval v podstatě stejné informace, jako se vyžadovaly při př́pravě komplexního hodnocení. Na prvním místě měli třídní učitelé uvést informace o morálně politickém profilu uchazeče, dále o jeho psychofyzických vlastnostech, o jeho zájmové orientaci a charakteristiku sociálního prostředí žáka (více viz Návrh postupu, 1982, n. s.). Základní nastavení príiímacího řízení na střední odborné školy tak zůstalo de facto nezměněno.

\section{Shrnutí a diskuse}

Předchozí raádky ukázaly, že přijímací řízení na středních odborných školách v socialistickém Československu bylo s výjimkou let kolem pražského jara zcela pod ideologickým vlivem vládnoucího komunistického režimu. V jeho průběhu uplatňoval myšlenky marxismu-leninismu, které - jak jinými slovy uvádí ve svém textu Václavík (1997) - hlásaly na jednu stranu ochraňování zájmů do té doby utlačovaných, ale na druhou stranu toto „ochraňování“ v praxi znamenalo utlačování jiných skupin. Hrubý (2018) k tomu koneckonců dodává, že v nedemokratických státech existují víceméně pouze instituce, které jsou plně závislé na centrální moci. To takovým režimům dává dalekosáhlé manipulační prostředky pro dosažení svých cílů, včetně různých perzekučních možností. V tomto směru administrativní akt ve formě přijímacího řízení na středních odborných školách nebyl výjimkou.

Vliv komunistické moci na průběh prijímacího řízení se přitom projevoval v několika rovinách. Zásadní roli hrála tzv. třídní a politická hlediska vtělená do posudků, které byly připravovány na základních školách v souvislosti s prŕípravou přihlášek na střední odbornou školu na každého žáka, respektive uchazeče, a i jeho rodiče. V této souvislosti např. Matějů (1991) či Kreidl $(2002 ; 2008)$ píšou o tom, že tato hlediska byla určující zejména při přijímacím řízení na gymnázia, respektive střední všeobecně vzdělávací školy. Jinak řečeno, že $\mathrm{v}$ případě středních odborných škol nehrála tak významnou roli. Výsledky našeho výzkumu ovšem ukazují, že minimálně v rovině oficiálních nařízení tomu tak nebylo. A spíše přispívají k názoru Jecha (1993), který tvrdí, že k těmto hlediskům se při přijímání žáků přihlíželo na všech středních školách, tedy i středních odborných i učňovských školách.

V tomto směru lze navíc dodat, že jedním z politických úkolů státní ideologie bylo odstranění nerovností ve vzdělávání, jak upozorňujeme i v rámci 
naší studie. Cílem přitom bylo jeho zpřístupnění širším masám. A to tak, aby v oblasti středního odborného školství byly zastoupeny všechny sociální trrídy $\mathrm{v}$ takovém poměru, $\mathrm{v}$ jakém byly tyto tř́́dy zastoupeny ve společnosti. Tedy zejména z řad dělníků a rolníků, jak upozorňuje nap̌r. Simonová (2006). Vzhledem k tomu, že se nikdy tohoto stavu nepodařilo dosáhnout (viz Katrňák, 2005), a to ani v oblasti stř̌edního odborného vzdělávání (Boháč \& Šulcová, 1979), lze se domnívat, že během přijímacího řízení na středních odborných školách se k třídnímu a politickému hledisku přihlíželo po celou dobu existence socialistického zř́zení. Otázkou v tomto směru může být, jak velká úloha a $\mathrm{v}$ jakém období byla těmto hlediskům připisována. $\mathrm{V}$ této spojitosti lze na základě našeho šetření konstatovat, že minimální roli, de facto žádnou, hrála tato hlediska pouze v letech 1967 a 1968, tedy zejména v období pražského jara. V rámci jiných období lze již jen usuzovat. Dosud jsme (zatím) neobjevili žádný dokument, který by tato hlediska z přijímacího řízení (alespoň v př́padě středních odborných škol) během socialistického režimu, vyjma roku 1968, zcela rušila a vyprávění našich narátorů je v tomto směru neurčité.

Výsledky našeho výzkumu dále ukazují, že výběr uchazečů na středních odborných školách $\mathrm{v}$ průběhu přijímacího řízení byl výrazným způsobem určován i hospodářskou politikou státu; tedy obdobně jako v př́padě jiných států bývalého socialistického východního bloku (viz nap̌r. Zajda, 2008). Vedle třídního a politického hlediska významnou úlohu během přijímacího řízení na střední odborné školy hrály i plány počtu přijatých, tj. směrná čísla či direktivní rozmíst’ování. Jinak řečeno, pokud daný uchazeč obstál z tř́ídního a politického hlediska a z hlediska jeho studijních předpokladů, nemuselo to znamenat jeho úspěšné přijetí na střední odbornou školu. Podle Kalinové (2012) tímto způsobem vlastně legálně docházelo k dalšímu omezování př́stupu některých jedinců $\mathrm{k}$ dalšímu studiu.

Výzkum průběhu přijímacího řízení na středních odborných školách během komunistického režimu v Československu vyvolal ovšem i některé metodologické otázky. Studium tohoto tématu by jen stěží mohlo obstát pouze na základě využití metody orální historie. V tomto př́ípadě se ovšem nejedná o její známé limity, jako je např́íklad skutečnost, že vypravování narátorů trpí určitými „nedostatky“, jako je zamlčování „,nepohodlných“ či kontroverzních témat, selektivní vzpomínání, mlčení v př́padech, kdy se téma pro narátora ukazuje jako př́liš citlivé, či zveličování vlastní úlohy ve zkoumaných událostech či jevech (viz např. Smith, 2017a; Vaněk \& Mücke, 2015; Zounek et al., 2015 ad.), ačkoliv jsme se s těmito problémy museli potýkat samozřejmě i my, a do určité míry proto limitují i naše nálezy. Vypravování narátorů jed noduše neposkytuje celý obrázek studované problematiky. Vytrácejí se jemné nuance, které se plně projeví až společně s dalšími zdroji zachycujícími makrohistorickou perspektivu dané problematiky. V tomto 
směru se tato skutečnost zcela projevila $\mathrm{v}$ našem textu př́ popisu úlohy ředitele během přijímacího řizení na střední škole zaměřené na gastronomické a ekonomické služby. Na tomto zachyceném př́iběhu se v plné síle ukazuje, jakým způsobem se dějiny každodennosti mohou vhodně doplňovat společně s makrohistorickou rovinou, jak píše např. Le Goff (1983). Samostatná vzpomínka na tuto událost by byla neúplná bez znalosti průběhu přijímacího řízení, zejména jeho pravidel. Stejně tak strohé popsání těchto pravidel by nás odsoudilo, jak jinými slovy ve svém textu uvádí opět Le Goff (1983), pouze k nudnému čtení se suchými fakty.

V této souvislosti je třeba dodat, že i zachycení makrohistorické roviny v př́ípadě zkoumání středního odborného školství, a jak ukazují studie i jiných autorů (např. Moree, 2013; Zounek et al., 2017a;), tak obecně školství v době socialistického Československa je rovněž silně limitováno. Důvodem je v naší studii již zmiňovaná obtížnější dostupnost tradičních, tj. archivních pramenů. $\mathrm{V}$ tomto světle lze však alespoň částečně tuto absenci nahradit dostupnějšími legislativními normami a dobovými periodiky, která při hlubším studiu mohou také významně napomoct k proniknutí do studované problematiky, jak se koneckonců ukázalo i v př́padě tohoto textu.

\section{Závěr}

Cílem našeho textu bylo zachytit průběh přijímacího řízení a jeho proměnu na stř̌edních odborných školách v období socialistického režimu v Československu. Sledovali jsme přitom, jakým způsobem se přijímací řízení na stř̌edních odborných školách v průběhu socialistického Československa proměňovalo. Zároveň jsme se ptali i na to, jakým způsobem bylo přijímací ŕízení na tyto školy ovlivňováno tehdejším socialistickým režimem pod vedením KSČ.

Nástup komunistické moci v Československu ovlivnil kromě jiného základní podobu přijímacího řízení na středních odborných školách, a to v podstatě hned v prvních letech vlády KSČ. Rozhodujícími faktory pro výběr uchazečů se stala tř́ídní a politická hlediska, která byla u jednotlivého žáka zkoumána na základě psaných posudků. Výběr nicméně dále probíhal na základě státního plánování. Toto direktivní rozmíst’ování žáků (nejen) na střední odborné školy bylo dáno zejména ekonomickými potřebami komunistického režimu. Ačkoliv byla $\mathrm{v}$ rámci prúijímacího řízení samozřejmě sledována i úroveň vzdělání každého žáka, případně jeho zájem o studium či zájem o obor samotný, tato rovina nebyla během přijímacího řízení ve srovnání s ostatním tolik zohledňována. Svědčí o tom koneckonců i skutečnost, že na „seznamu“ požadavků se hledisko úrovně vzdělání samotného uchazeče $\mathrm{v}$ oficiálních dokumentech objevovalo vždy až po zohlednění tř́ídního a politického hlediska. 
V dalších letech docházelo již spíše ke zpřesnění některých organizačních záležitostí príiímacího řízení, obecně ke zjednodušení celého procesu, ale zároveň i k utužení celého systému na základě zkušeností získaných z realizace přijímacího řízení $\mathrm{v}$ předchozích letech. Výjimku $\mathrm{v}$ tomto směru představoval pouze rok 1967 a 1968, kdy výrazným způsobem při výběru uchazečů převažovala úroveň vzdělání uchazeče a zohledňování třídního a politického hlediska, stejně jako ekonomické zájmy státu byly zcela upozaděny.

Studie také odhalila, že ačkoliv stát nastavil jasná pravidla pro výběr uchazečů ke studiu na středních odborných školách, existovaly možnosti, které např́ḱlad ředitelům škol, jako předsedům přijímacích komisí, do určité míry umožňovaly sledovat i své vlastní cíle. V tomto směru se ukazují i některé limity naší studie. Výsledky našeho výzkumu jsou totiž založeny na výpovědích narátorů, kteří byli pasivními odpůrci režimu, nebo dodržování režimních postupů vnímali jako nutnou součást jejich profese. Nikdo z narátorů nebyl výraznou součástí prorežimních hnutí. Důvod je prostý, i přes veškeré naše snahy se nám nepodařilo zatím získat takové narátory, kteří by zaujímali v době socialistického Československa proaktivní režimní postoj a zároveň se $\mathrm{s}$ námi chtěli podělit o své vzpomínky. V souvislosti s tématem přijímacího řízení by proto bylo velmi zajímavé a přínosné získat i osobité zkušenosti z řad tehdejších školských funkcionářů. Např́iklad těch, kteří působili ve školských orgánech při ONV či KNV, popř́padě v ČSM a ROH apod., a měli tak možnost plně sledovat a ovlivňovat průběh přijímacího řízení. I přes tyto limity se ovšem domníváme, že naše studie může otevřít nejen odbornou, ale i širší veřejnou diskusi. A to jak v souvislosti s príijímacím řízením na těchto školách, tak i obecně $\mathrm{k}$ tématu odborného vzdělávání ve státech se socialistickou zkušeností.

Výzkum přijímacího řízení na středních odborných školách otevřel i př́padná nová výzkumná témata. $V$ tomto směru především ve spojitosti s úlohou Výzkumného ústavu odborného vzdělávání v rámci odborného vzdělávání v období před rokem 1989, či již v úvodních částech tohoto textu zmiňovaný (nejen) průběh přijímacího řízení $\mathrm{v}$ mimořádných způsobech studia, jako bylo např. večerní studium, dálkové studium či studium při zaměstnání ad., kterým obdobně jako přijímacímu řízení na středních odborných školách také nebyla dosud věnována v podstatě žádná pozornost.

\section{Poděkování}

Studie vznikla v rámci řešení projektu s názvem Střední odborná škola v socialistickém Československu pohledem dějin každodennosti. Orálně historické rozhovory s učiteli (číslo projektu 19-24776S) financovaného Grantovou agenturou České republiky. Autoři děkují za poskytnutou podporu. 


\section{Bibliografie}

\section{Archivni prameny}

Dưvodová zpáva k. vládnimu návrbu zákona o školské soustavě a vąèláváni učitelu (školský zákon) ze dne 15. dubna 1953. (1953). https://www.psp.cz/eknih/1948ns/tisky/t0708_01.htm

Metodický pokyn ke komplexnimu hodnoceni žáku končicich povinnou školni docházku - zadání. (1971). Fond Ministerstva školství 1948-1989 (kart. 829, 1967-1978, sg. 17d5). Národní archiv.

Metodický pokyn pro vypracováni komplexního hodnoceni zááư základnich devitiletých škol končicich školní docháqku. (1971). Fond Ministerstva školství 1948-1989 (kart. 829, 1967-1978, sg. 17d5). Národni arcbiv.

Návrh postupu organizačního a obsabovébo zabezpečení prechodu žákư do střednich škol prúplnèni povinné desetileté školni docházky - predeéžné prípominkové rízeneni. (1982). Fond Ministerstva školství 1948-1989 (kart. 819, 1981-1988, sg. 17a). Národni archiv.

Prípominky k některým školským otázkám. (1968). Sekretariát ministerstva, fond Ministerstvo školství (MŠMT) 1967-1992 (kart. 188, sg. 17+místo P-Ž). Národni archiv.

\section{Legislativni normy}

Prozatímní směrnice o přijímání ke studiu na středních všeobecně vzdělávacích školách, odborných školách, středních odborných školách, konzervatořích a do souvislého pětiletého studia v roce 1969, č. j. 24646/68-II/3a. (1968). Véstník ministerstva školství a ministerstva kultury a informací, 24(22), 317-321.

Přijímání uchazečů do středních škol pro pracující, odborných škol, středních odborných škol (i pedagogických škol), stř̌edních všeobecně vzdělávacích škol a konzervatoří, č. j. 54 129/60-II/5. (1961). Vèstník ministerstva škeolství a kultury, 17(32), 17-23.

Směrnice, jimiž se mění a doplňují směrnice ministerstva školství ČSR o přijímání ke studiu na školách poskytujících střední a vyšší vzdělání, č. j. 7914/72-213. (1972). Věstník Ministerstva škoolstvi a ministerstva kultury České socialistické republiky, 28(2), 34-36.

Směrnice, jimiž se mění a doplňují směrnice ministerstva školství ČSR o přijímání ke studiu na školách poskytujících střední a vyšší vzdělání, č. j. 10 804/71-213. (1971). Věstník Ministerstva školství a ministerstva kultury Ceské socialistické republiky, 27(4), 37-39.

Směrnice o přijímání ke studiu na školách poskytujících střední a vyšší vzdělání, č. j. 14.550/70-II/3a. (1970). Vèstník Ministerstva školství a ministerstva kultury Céské socialistické republiky, 26(3-4), 21-27.

Směrnice pro přijímání ke studiu na středních školách a do souvislého pětiletého studia na odborných učilištích a učňovských školách, č. j. 17 912/67-II/5. (1967). Věstnik ministerstva škeolství a ministerstva kultury a informací, 23(15), 135-137.

Směrnice pro rozmist'ování mládeže a pro přijímání ke studiu na středních školách. Výnos ministerstva školství a kultury ze dne 25. ledna 1962, č. j. 5222/62-II/5. (1962). Vèstník ministerstva školstvi a kultury, 18(4), 39-46.

Směrnice pro rozmist’ování mládeže a pro přijímání ke studiu na stř̌edních školách - změna, č. j. 46 312/62-II/5. (1962). Věstník ministerstva školství a kultury, 18(33), 377-378.

Směrnice pro rozmist'ování mládeže a pro přijímání ke studiu na stř̌edních školách - doplněk, č. j. 53 499/64-X/I. (1965). Věstnik ministerstva školství a kultury, 21(2), 24.

Vládní nařízení 2/1952 Sb., o rozmist’ování absolventů vysokých škol a výběrových odborných. (1952). Věstník Ministerstva školství, věd a umèní, 8(10), 203. 
Zákon č. 241/1948 Sb., o prvnim pètiletém hospodárském plánu rozvoje Československé republiky (zákon o pétiletém plánu). (1948). https://www.noveaspi.cz/products/lawText/1/17989/1/2/zakon-c-241-1948-sb-o-prvnim-petiletem-hospodarskem-planu-rozvoje-ceskoslovenskerepubliky-zakon-o-petiletem-planu/zakon-c-241-1948-sb-o-prvnim-petiletem-hospodarskem-planu-rozvoje-ceskoslovenske-republiky-zakon-o-petiletem-planu (Wolters Kluwer ČR, 2020-04-12).

Zákon č. 31/1953 Sb., o školské soustavě a vzdèláváni učitelů (školský zákoon). (1953). https://www. noveaspi.cz/products/lawText/1/27134/1/2/zakon-c-31-1953-sb-o-skolske-soustave-avzdelavani-ucitelu-skolsky-zakon/zakon-c-31-1953-sb-o-skolske-soustave-a-vzdelavaniucitelu-skolsky-zakon (Wolters Kluwer ČR, 2020-04-12).

Zákon č. 95/1948 Sb., o základni úpravé jednotnébo školství (školský qákon). (1948). https://www. noveaspi.cz/products/lawText/1/17263/0/2/zakon-c-95-1948-sb-o-zakladni-uprave-jednotneho-skolstvi-skolsky-zakon/zakon-c-95-1948-sb-o-zakladni-uprave-jednotneho-skolstvi-skolsky-zakon (Wolters Kluwer ČR, 2020-04-12).

Závěrečné zkoušky na středních školách a přijímání žáků do výběrových škol třetího stupně - Výnos MŠVU z 15. března 1951 č. 17 345-II. (1951). Věstník ministerstva školství, věd a uměni, 7(8), 75-81.

\section{Literatura}

Abrams, L. (2016). Oral history theory. Routledge, Taylor \& Francis Group.

Boguszak, M., Gabal, I., \& Matějů, P. (1990). Ke koncepcím vývoje sociální struktury v ČSSR: Př́íspěvek k sebereflexi československé sociologie. Sociologický časopis, 26(3), 168-186.

Boháč, A., \& Šulcová, V. (1979). Ceskoslovenské stréedni odborné školy od osvobození do dneškea. VÚOŠ.

Disman, M. (2011). Jak se vyrábi sociologická znalost: Príručka pro uživatele. Karolinum.

Eckert, A., \& Jones, A. (2002). Historical writting about everyday life. Journal of African Cultural Studies, 1(15), 5-16. https://doi.org/10.1080/13696810220146100

Greinert, W-D., \& Hanf, G. (Eds.). (2004). Towards a history of vocational education and training (VET) in Europe in comparative perspective. European Centre for the Development of Vocational Training.

Grootings, P. (1993). VET in transition: An overview of changes in three East European countries. European Journal of Education, 28(2), 229-240. https://doi.org/10.2307/1503389

Historická statistická ročenka ČSSR. (1985). Nakladatelství technické literatury.

Hrubý, K. (2018). Cesty komunistickou diktaturou: Kritické studie a eseje. Argo.

Janesick, J. V. (2010). „Stretching“ exercises for qualitative researchers. SAGE Publications.

Jech, K. (1993). Stránkami soudobých dějin: Sborník statí k pètašedesátinám historika Karla Kaplana. Ústav pro soudobé dějiny Akademie věd České republiky.

K novému způsobu výběru žáků. (1957). Odborná škeola, 4(4), 97-100.

Kalinová, L. (2012). Konec nadějím a nová očekáváni: K dějinám české společnosti 1969-1993. Academia. Katrňák, T. (2005). Trídni analýza a sociálni mobilita. Centrum pro studium demokracie a kultury.

Kestere, I., \& Kalke, B. (2018). Controlling the image of the teacher's body under authoritarianism: The case of Soviet Latvia (1953-1984). Paedagogica Historica, 54(1-2), 184-203. https://doi.org/10.1080/00309230.2017.1358289 
Kourová, P. (2017). Lánská akce. „Nejvíce nám záleží na hornické mládeži““ Marginalia Historica, 8(1), 97-127.

Kreidl, M. (2002). Trendy ve výběru střední školy v socialistickém Československu. Sociologický ćasopis, 38(5), 565-592.

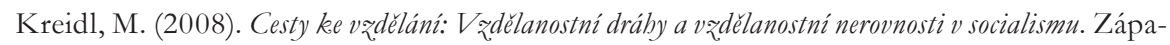
dočeská univerzita v Plzni.

Kučerová, S. R., Dvořák, D., Meyer, P., \& Bartůněk, M. (2020). Dimensions of centralization and decentralization in the rural educational landscape of post-socialist Czechia. Journal of Rural Studies, 74, 280-293. https://doi.org/10.1016/j.jrurstud.2019.12.018

Kudláčová, B. (Ed.). (2019). Pedagogické myslenie, školstvo a vądelávanie na Slovensku v rokoch 1945-1989. Trnavská univerzita v Trnavě.

Kudláčová, B., \& Šebová, N. (2019). Illegal confessional education of children in Slovakia in the period of Socialism (political and religious context). Paedagogica Historica, 1-22. https:// doi.org/10.1080/00309230.2019.1589539

Le Goff, J. (1983). Later history. Past and Present, 100(1), 14-28.

Linhartová, M. (1976). K přijímacímu řízení na OŠ. Odborná škola, 24(2), 23.

Lukš, J. (1974). Zpráva z výzkumu prijímacího ř́zenin na středni školy. VÚOŠ.

Matějů, P. (1991). Kdo získal a kdo ztratil v socialistické redistribuci. 40 let vývoje vzdělanostních nerovností v Československu. Sociologický časopis, 27(1), 13-38.

Mincu, M. E. (2016). Communist education as modernisation strategy? The swings of the globalisation pendulum in Eastern Europe (1947-1989). History of Education, 45(3), 319-334. https://doi.org/10.1080/0046760X.2015.1127432

Moree, D. (2013). Učitelé na vlnách transformace: Kultura školy pred rokem 1989 a po něm. Karolinum.

Mužíková, L. (1950). Dílčí pohled na politickou a odbornou úroveň absolventů některých z postupových typů našich škol. Odborná škola, 3(9-10), 266-273.

Nilsson, A. (2014). The unknown story: Vocational education for adults in Sweden 1918-1968. History of Education, 43(5), 615-634. https://doi.org/10.1080/0046760X.2014.930187

Olšáková, D., \& Janáč, J. (2018). Kult jednoty: Stalinský plán prétvoření prírody v Československu 1948-1964. Academia.

Opelík, J. (2000). Lexikon české literatury. Osobnosti, díla, instituce, $M-K ̌$. Academia.

Otáhal, M. (2002). Normalizace 1969-1989: Př́spèveke ke stavu bádání. Ústav pro soudobé dějiny Akademie věd České republiky.

Portelli, A. (2015). What makes oral history different. In R. Perks \& A. Thomson (Eds.), The oral history reader (s. 21-30). Routledge.

Průcha, J. (2019). Odborné školstvi a odborné vz̨èlávání: Fungováni systému, problémy praxe a výzkum. Wolters Kluwer.

Rahi-Tamm, A., \& Saleniece, I. (2016). Re-educating teachers: Ways and consequences of sovietisation in Estonia and Latvia (1940-1960) from the biographical perspective. Journal of Baltic Studies, 47(4), 451-472. https://doi.org/10.1080/01629778.2016.1263035

Rýdl, K. (2010). K vývoji správy a rízeni školstvi v českých zemich. Univerzita Pardubice.

Řezáč, V. (1951). Nástup. Československý spisovatel.

Sedlák, P. (2013). Proč tak snadno? Silné a slabé stránky revize vykládání diktatury KSČ a jejího nástupu v únoru 1948. Déjiny-teorie-kritika, 10(1), 30-55. 
Simonová, N. (2006). Vzdělanostní nerovnosti a vzdělanostní mobilita v období socialismu. In P. Matějů \& J. Straková (Eds.), (Ne)rovné šance na vądèlání. VZ̃dèlanostni nerovnosti v České republice (s. 62-91). Academia.

Simonová, N. (2011). Vždělanostni nerovnosti v české společnosti. Vývoj od počátku 20. století do současnosti. Sociologické nakladatelství.

Smith, G. (2017a). Oral history. Routledge.

Smith, K. E. (2017b). Moscow 1956. The silenced spring. Harvard University Press.

Somogyvári, L. (2019). Political decision-making in socialist education: A Hungarian case study (1958-1960). History of Education, 48(5), 664-681. https://doi.org/10.1080/004676 0X.2019.1590651

Stenström, M., \& Virolainen, M. (2014). The history of Finnish vocational education and training. Finnish Institute for Educational Research University of Jyväskylä.

Swain, G., \& Swain, N. (1998). Eastern Europe since 1945. MacMillan Press.

Švanda, I. (2000). Výzkumný ústav odborného školství padesátiletý. Retrospektivní pohled na jeho výzkumnou činnost. Zpravodaj výzkumného ústavu odborného školství, (5), 1-32.

Václavík, V. (1997). Cesta ke svobodné skoole: Kapitoly ze srovnávaci pedagogiky. Líp.

Vaněk, M., \& Houda, P. (2016). Strǐpky moz̨aiky: Každodenni život české společnosti v obdobi normalizace a transformace z pobledu orální bistorie. Fakulta humanitních studií Univerzity Karlovy v Praze.

Vaněk, M., \& Mücke, P. (2015). Treti strana trojúhelniku: Teorie a praxe orální historie. Karolinum.

Vorlíček, Ch. (2004). České školství 1945-2000. In E. Walterová (Ed.), Česká pedagogika: Promény a výzvy: Sborník k životnimu jubileu profesora Jiř́ho Kotáska (s. 119-176). Univerzita Karlova.

Walterová, E. (2004). Úloha školy v rozvoji vz̨èlanosti. Paido.

Wollschläger, N., \& Guggenheim, É. F. (Eds.). (2004). A history of vocational education and training in Europe - From divergence to convergence. European Journal Vocational Training, $32,1-3$.

Zajda, J. (2008). Education for work in the USSR: Vocational education and training during the 1970s. Political Crossroads, 15(1), 87-106. https://doi.org/10.7459/pc/15.1.05

Zounek, J., \& Šimáně, M. (2014). Úvod do studia dějin pedagogiky a školství: Kapitoly z metodologie bistoricko-pedagogického výzkumu. Masarykova univerzita.

Zounek, J., Knotová, D., \& Šimáně, M. (2015). Výzkum soudobých dějin pedagogiky a školství: K metodologickým otázkám historicko-pedagogického výzkumu. Studia paedagogica, 20(3), 89-112. https:// doi.org/10.5817/SP2015-3-6

Zounek, J., Šimáně, M., \& Knotová, D. (2017a). Normálni šivot v nenormálni době. Základni školy a jejich učitelé (nejen) v obdobi normalizace. Wolters Kluwer.

Zounek, J., Šimáně, M., \& Knotová, D. (2017b). Socialistická základni škola pobledem pamètníkư. Sonda do života učiteliu v Jihomoravském kraji. Wolters Kluwer.

Zounek, J., Šimáně, M., \& Knotová, D. (2018). "You have betrayed us for a little dirty money!" The Prague Spring as seen by primary school teachers. Paedagogica Historica International Journal of the History of Education, 54(3), 320-337. https://doi.org/10.1080/00309230.2017.1 394884

Zwettler, O., Vaculík, J., \& Čapka, F. (1996). Úvod do studia dějepisu a technikea historikovy práce. Masarykova univerzita. 


\section{Kontakt na autory}

Michal Šimáně

Oddělení sociálních věd, Institut celoživotního vzdělávání, Mendelova univerzita v Brně E-mail: simane@mendelu.cz

Lenka Kamanová

Oddělení sociálních věd, Institut celoživotního vzdělávání, Mendelova univerzita v Brně E-mail: lenka.kamanova@mendelu.cz

\section{Corresponding authors}

Michal Šimáně

Department of Social Sciences, Institute of Lifelong Learning, Mendel University in Brno E-mail:simane@mendelu.cz

Lenka Kamanová

Department of Social Sciences, Institute of Lifelong Learning, Mendel University in Brno E-mail: lenka.kamanova@mendelu.cz 
